Review

\title{
Recent trends on seaweed fractionation for liquid biofuels production
}

\author{
Pablo G. del Río ${ }^{\mathrm{a}}$, Joana S. Gomes-Dias ${ }^{\mathrm{b}}$, Cristina M.R. Rocha ${ }^{\mathrm{b}}$, Aloia Romaníb,*, Gil Garrote ${ }^{\mathrm{a}}$, \\ Lucília Domingues $^{\mathrm{b}}$
}

${ }^{a}$ Department of Chemical Engineering, Faculty of Science, University of Vigo Campus Ourense, As Lagoas, 32004 Ourense, Spain

${ }^{\mathrm{b}}$ CEB-Centre of Biological Engineering, University of Minho, Campus Gualtar, 4710-057 Braga, Portugal

\section{G R A P H I C A L A B S T R A C T}

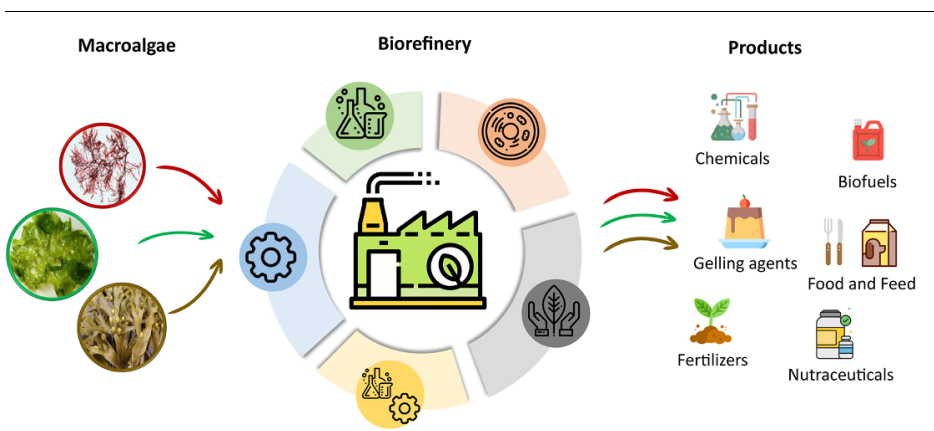

A R T I C L E I N F O

\section{Keywords:}

Macroalgae

Seaweed

Fractionation

Pretreatments

Biofuels

Biorefinery

\begin{abstract}
A B S T R A C T
Concerns about fossil fuels depletion has led to seek for new sources of energy. The use of marine biomass (seaweed) to produce biofuels presents widely recognized advantages over terrestrial biomasses such as higher production ratio, higher photosynthetic efficiency or carbon-neutral emissions. In here, interesting seaweed sources as a whole or as a residue from seaweed processing industries for biofuel production were identified and their diverse composition and availability compiled. In addition, the pretreatments used for seaweed fractionation were thoroughly revised as this step is pivotal in a seaweed biorefinery for integral biomass valorization and for enabling biomass-to-biofuel economic feasibility processes. Traditional and emerging technologies were revised, with particular emphasis on green technologies, relating pretreatment not only with the type of biomass but also with the final target product(s) and yields. Current hurdles of marine biomass-to-biofuel processes were pinpointed and discussed and future perspectives on the development of these processes given.
\end{abstract}

\section{Introduction}

The growth in fossil fuel-based energy consumption has implied many ecological and environmental issues related to global warming, climate change or the unceasing emission of greenhouse gases, such as carbon dioxide (Appiah-Nkansah et al., 2019). Furthermore, this nonrenewable type of energy is depleting at staggering speed, for example, reserves of oil are estimated to disappear within the next 25-30 years
(Ong et al., 2019). Consequently, the search for renewable, economical and eco-friendly energy sources is the main target of this century, being one of the most important those based in biomass refinery, also known as biorefinery (Amoah et al., 2019; Yang et al., 2019). The utilization of biomass-based fuels not only would mitigate the global warming, but also reduce the emission of carbon dioxide due to the prior consumption of this gas by the biomass via photosynthesis, resulting in carbonneutral emission (Amoah et al., 2019).

\footnotetext{
* Corresponding author.

E-mail address: aloia@ceb.uminho.pt (A. Romaní).
} 
Biomass can be divided into several generations, depending on different features. First generation feedstock consists of food or derivedfood crops such as barley, corn, palm oil, potato sugar beet, rice, soybean oil or sugarcane, among others. These biomasses have a great sugar or starch content, being optimal for the production of biofuels. However, the employment of first generation feedstock could bring about some socio-economic and environmental issues, for example, the growth of the demand, hence the increase of the price, being cause of depletion of the resources or provoking soil degradation due to over fertilization (Robak and Balcerek, 2018).

Second generation feedstock comprise the lignocellulosic biomass, including not only forest materials, but also grasses, energy crops, agricultural residues and crop or municipal wastes. In this case, lignocellulosic materials overcome the main disadvantage of the first generation, diminishing the concern of food sustainability, while maintaining a low and stable price with no extra demand of land (Alalwan et al., 2019). Moreover, this biomass is characterized by its ubiquity, sustainability, availability and high production capacity. Nevertheless, the main restraint with second generation feedstocks resides in the complex internal structures due to lignin presence, that may hinder cellulose and hemicelluloses accessibility (Dave et al., 2019). Eventually, algal biomass has been employed as third generation feedstock, while fourth generation feedstock employs genetically modified algal biomass in order to reach better hydrogen to carbon yields and to produce an artificial carbon sink to remove or reduce carbon emissions (Alalwan et al., 2019; Sudhakar et al., 2018).

In this way, algae are the third generation feedstock and currently stand out as a potential biomass to obtain biofuels (Michalak, 2018) due to some advantages such as: i) ubiquity, ii) low rate of biomass fluctuation owing to overpopulation, iii) production of the majority of oxygen in the planet with a high absorption of annual $\mathrm{CO}_{2}$, iv) higher photosynthetic efficiency (6-8\%) than terrestrial biomass (1.8-2.2\%), v) low consumption of water, vi) no alteration of human food supply, vii) no competition for arable land, viii) capacity of growing in a wide range of territories like saline water or wastewater, ix) absence or low lignin content; $\mathrm{x}$ ) potential to obtain high-added value products (cosmetics, drugs, pigments, biofertilizers, food additives...) and xi) ability to achieve larger production rates of biomass than land-based feedstock (in terms of land surface employed) (Rodríguez-Jasso et al., 2013; Ruiz et al., 2013; Sirajunnisa and Surendhiran, 2016). In a recent study, the US Energy Department has estimated (under specific conditions) that the biofuel productivity from seaweed is two and five-fold higher than ethanol productivity obtained from sugarcane and corn, respectively (Soliman et al., 2018).

Depending on the size, algae can be separated into two main groups: macroalgae and microalgae. Macroalgae, known as well as seaweed, consist of multicellular organisms composed of high quantities of carbohydrates. This property, besides the little or no lignin content, make them interesting for bioethanol or biobutanol production (Dave et al., 2019; Hong et al., 2017; Jin et al., 2013; Kostas et al., 2016). Moreover, their size goes from a few millimeters to many tens of meters (Ganesh Saratale et al., 2018). On the contrary, microalgae are unicellular organisms with sizes lower than $0.4 \mathrm{~mm}$ of diameter, and have a higher content of lipids, making them ideal for biodiesel production (Jin et al., 2013).

Oceans and seas occupy more than $70 \%$ of the planet's surface, which enable the sustainable cultivation and harvesting of a huge quantity of this potential feedstock. In this sense, not only the production and recollection of these seaweeds is feasible, but also the employment and exploitation of invasive seaweed, which can be a problem for native species due to the competition of light, space and resources (Balboa et al., 2016; Ruiz et al., 2013), arises as a promising biofuel resource.

Due to the growing scientific interest in macroalgae exploitation for biofuels production, this topic is approached in several reviews (Chen et al., 2015; Chow et al., 2013; Ghadiryanfar et al., 2016; Khoo et al.,
2019; Sirajunnisa and Surendhiran, 2016). More specifically, liquid fuels (mainly bioethanol production) from macroalgae resource have been reviewed by Jiang and co-workers (2016). Generally, these reviews gather information only about pretreatment used for ethanol production. Differently to other reviews, this one is focused on the pretreatment for a suitable fractionation of marine biomass following a biorefinery concept. The pretreatment not only should be used to obtain fermentable sugars to produce biofuels, but also to recover other valueadded compounds (namely, protein, phenolic compounds, etc.) that enable feasibility of marine biobased refinery. Moreover, these processes should contribute to environmental sustainability. These issues need to be integrated in the selection of pretreatment. In here, the main interesting sources of macroalgae for biofuels production are identified and the main pretreatments used for the seaweed biomass processing are approached from an integrated perspective. Moreover, the main drawbacks for a large-scale utilization of these renewable resources are discussed.

\section{Seaweed as feedstock}

\subsection{Available sources for biofuels}

Algae biomass is readily available, either from wild harvest or from aquaculture cultivation. From the more than 200 seaweed species with commercial value, only about 10 are intensively cultivated. Nevertheless, from the 30.4 million tons of seaweeds produced in 2015 , 29.4 million tons corresponded to cultured seaweeds, according to data from the Food and Agriculture Organisations (FAO) of the United Nations (Ferdouse et al., 2018). Cultivation and harvesting are quite straightforward, which is a significant advantage over microalgae. Offshore cultivation in open water farms using longlines are the most common systems, but near shore bottom cultivation, rock-based cultivation or on-land (onshore) cultivation are also used (Kim et al., 2017). These farms are usually located in lagoons or sheltered bays, though the presence of significant water motion is important (Sirajunnisa and Surendhiran, 2016). Harvest can be made manually or mechanically (Sudhakar et al., 2018).

Seaweeds have long been used mostly for food/feed applications and in the hydrocolloids industry. Albeit the many available macroalgae species (about 9000 ), only a small fraction is commercially exploited (Sirajunnisa and Surendhiran, 2016), leaving a significant range of other underused macroalgae available for unexplored or underexplored applications.

Selection of appropriate strains is a crucial step (John et al., 2011; Sirajunnisa and Surendhiran, 2016). Factors such as growth rate, light requirements, morphology, seasonality, behavior under adverse conditions, nutrient needs, starch/cellulose content, ability to dominate other wild strains or epiphytes, resistance/resilience to changes (including temperature, salinity, light or location), carbon storage ability, photosynthetic yield, biomass productivity, carbohydrate content, possible high-value co-products, among others, are important to consider. Furthermore, production, harvest season or pre-harvest treatments can be tuned to maximize the potential amount of fermentable sugars in order to get maximum productivity in biofuels.

Seasonal or occasional green, red or brown/golden tides can provide huge amounts of seaweeds that rapidly degrade and may cause severe environmental issues. In fact, invasive macroalgae have been considered as a great menace for autochthonous species and global marine natural resources. The insertion of non-native species can alter the current habitats owing to the shifts in communities and trophic chains, which can cause a decrease of biodiversity and change in the ecological stability of invaded ecosystems. This invasion may be caused naturally, however, humans' activities, for example heavy naval traffic, import of shellfish products or aquaculture, can hasten this situation in both terrestrial and marine ecosystems (Pérez-López et al., 2014).

Seasonal harvesting is proposed as a control strategy as no methods 
for prevention and removal of invasive seaweeds have been successful. In this way, one of the most interesting ways of valorization of invasive seaweed is the production of biofuels, turning a problem into a benefit, i.e., finding a double environmental and economic advantage: the removal of a hazardous material and the economical revalorization of the marine biomass, which is actually useless and without value (De Ramon N'Yeurt and Iese, 2015; del Río et al., 2019; Milledge et al., 2016).

On the other hand, the increasing interest and spreading of other seaweed-based systems, such as wastewaters treatment (to decrease nitrogen and phosphorus or heavy metals content) and nutrient bioextraction from urbanized estuarine waters (Rocha et al., 2019) or multitrophic aquaculture systems, IMTA (Alexander and Hughes, 2017), both onshore or offshore, can also provide a new, more sustainable and significant source of seaweeds. These processes use seaweeds as biofilters, using solar energy and the excess of nutrients to produce new biomass while purifying the effluents before they are disposed into the environment. Huge amounts of biomass are produced that have to be mechanically removed. This biomass can be used as byproducts for other industries, namely for biofuel production, in a biorefinery/circular economy approach. In this case, the size of the macroalgae simplifies and reduces costs of the cultivation and harvesting procedure (Parsa et al., 2019).

Besides the direct human consumption as food, the main seaweed processing industry is the hydrocolloids extraction sector (alginate, carrageenan and agar). In fact, seaweeds are the base for almost $40 \%$ of the total world hydrocolloids market (Ferdouse et al., 2018). The estimated value of the seaweed hydrocolloids (also known as phycocolloids) sales volume in 2015 was 93000 metric tons corresponding to ca 1000 million USD sales (Porse and Rudolph, 2017). Though hydrocolloids extraction yields are generally high, a significant amount of solid residues is still generated. For instance, for agar, these wastes can represent up to $30 \%$ of the total seaweed biomass used (Meinita et al., 2017; Shukla et al., 2016), with a significant content in carbohydrates. These wastes can also be an interesting feedstock for biofuels.

\subsection{Chemical composition}

The multipart composition of seaweeds makes them broadly employed in different types of industry based on biorefinery, especially due to their polysaccharides or hydrocolloids such as agars, carrageenan and alginates. Moreover, they contain carbohydrates, proteins, lipids, vitamins and minerals, which content can vary depending on the season and area of production (Torres et al., 2019).

Generally, seaweeds have a really high water content (70-90\% fresh weight) and are mostly composed by carbohydrates $(25-77 \%$ dry matter basis, dry matter), followed by proteins (5-43\% dry matter), minerals (with an ash content of 9-50\% dry matter) and lipids (1-5\% dry matter) (Jung et al., 2013; Offei et al., 2018; Praveen et al., 2019). The main carbohydrates found in seaweed are cellulose, starch, sucrose, ulvan, carrageenan, agar, laminarin, mannitol, alginate, fucoidan. Lignin is normally absent or present for a limited range of seaweeds in low amount, which is an advantage over traditional lignocellulosic biomass for biofuels' applications. Furthermore, the low lipid and high carbohydrate contents makes them good candidates for alcohol-based fuels (Sirajunnisa and Surendhiran, 2016).

Seaweeds can be separated into three different groups depending on their pigmentation: green, red and brown seaweeds and, in each specific group, the variation of carbohydrates is distinctive (Jung et al., 2013; Michalak, 2018). Table 1 shows the chemical composition of the three types of seaweed. Furthermore, external factors such as time and location of sampling, salinity gradient, depth of cultivation site and type and size of cultivation reactor can lead to significant variations in seaweed composition (Kumar et al., 2013; Møller et al., 2016; PeñaRodríguez et al., 2011a; Robin et al., 2017; Sharma et al., 2018). The methodology used for the determination of carbohydrate composition is also a factor to consider, since different methods lead to different results
(Manns et al., 2014). In fact, there is no reliable standard protocol of analysis and this is considered one challenge for the exploitation of seaweeds (Van Hal et al., 2014). Thus, in order to employ seaweed as a carbon source for biofuels, it is essential to collect reliable information about their composition.

\subsubsection{Green seaweeds}

Green seaweeds, also known as Chlorophyceae (Li et al., 2014), comprise the majority group with up to 1500 species. Bays, estuaries or tide pools are the zones where it is more likely to find them. Regarding the morphology, they have a simple thallus, and generally grow as filamentous spongy fingers or paper-thin sheets. Their photosynthetic pigments are essentially chlorophyll $A$ and $\mathrm{B}$, and carotenoids (Jung et al., 2013; Sudhakar et al., 2018). Moreover, green algae carbohydrate content varies between 40 and $60 \%$ dry matter, and it mainly consists of polysaccharides as ulvan, starch and cellulose (Michalak, 2018; Praveen et al., 2019). Ulvan is mainly composed by $\alpha$ - and $\beta$ $(1,4)$-linked units of rhamnose, xylose, galactose, glucuronic acid and iduronic acid and several repeating disaccharides (such as $\beta$-D-glucuronic acid $(1,4)$-linked to $\alpha$-L-rhamnose 3 -sulfate) (Kidgell et al., 2019), while both starch and cellulose are composed by glucose units, but with different spatial configurations. Cellulose has a regular linear chain with 1,4- $\beta$-glycosidic bonds in parallel, developing a stable crystalline structure, also supported by hydrogen linkages and Van der Waals forces, making them very unaffected by enzymatic and physical breakdown. On the other hand, starch has an open and weakly linked helical configuration, making it easier to breakdown with enzymes, via chemical or physical action (Maneein et al., 2018; Offei et al., 2018). Some of the main species of green algae are Halimeda, Ulva and Codium (Sudhakar et al., 2018).

\subsubsection{Red seaweeds}

Red seaweeds, also known as Rhodophyceae, are the most abundant and extensively spread, and are composed by about 4000 species. These seaweeds tend to grow in deep cold waters or warm shallow waters, forming filaments or sheets, tending to parasite other algae. Furthermore, as photosynthetic pigments, they have chlorophyll A and phycobilins (Sudhakar et al., 2018). The $40-70 \%$ of their dry weight is constituted by carbohydrates, especially polysaccharides such as carrageenan, agar and cellulose (Offei et al., 2018; Praveen et al., 2019). Carrageenan, the main carbohydrate in carrageenophytes, comprise a polysaccharide of sulfated galactans joined by $\beta-1,4-$ and $\alpha-1,3$-glycosidic linkages, which in turn is composed by units of galactose with different ester-sulfate contents $(15-40 \% \mathrm{w} / \mathrm{w})$. Also, carrageenan is classified as $\kappa, \imath$ and $\lambda$ types, depending on their content in ester-sulfates and galactose units, which determine their solubility in potassium chloride and their gel-forming capacity (Yun et al., 2016; Zhang et al., 2019). The chief component of agar, the main carbohydrate in agarophytes, is agarose, followed by agaropectin. The former is a heteropolysaccharide formed by D-galactose and 3,6-anhydro-L-galactose units linked by $\alpha-1,3-$ and $\beta-1,4-$ glycosidic bonds, while the latter consists of a polysaccharide also formed by galactose units, but very likely to be substituted by ester-sulfates, methyl groups or pyruvates (Yun et al., 2016). Cellulose is mainly composed of glucose units bonded the same way than green seaweeds, however, some xylose and mannose units can be found linked by 1,3 and 1,4- $\beta$-glycosidic bonds, respectively, acting as substitute for glucose in some cases (Praveen et al., 2019). Some of the chief species of red algae are Corallina, Gracilaria, Palmaria and Asparaposis (Sudhakar et al., 2018).

\subsubsection{Brown seaweeds}

Brown seaweeds are classified as Phaeophyceae (Cardoso et al., 2014) and their characteristic photosynthetic pigments are chlorophylls (a and c) and carotenoids (mainly fucoxanthin). There are around 1500 different species. They can grow up to $100 \mathrm{~m}$ long, have a complex thallus and grow preferably in shallow and cold waters (Sudhakar et al., 
Table 1

Chemical composition and monosaccharide profile of three representative seaweeds.

\begin{tabular}{|c|c|c|c|}
\hline & Red Seaweed & Green Seaweed & Brown Seaweed \\
\hline $\begin{array}{l}\text { Proximate compositiong/100 g dry } \\
\text { biomass }\end{array}$ & Gelidium amansii & Ulva sp. & Saccharina latissima \\
\hline Ash & $2.5-4.8$ & $18.0-49.6$ & $8.7-41.2$ \\
\hline Lipid & $0.7-7.4$ & $1.0-3.5$ & $0.6-3.4$ \\
\hline Protein & $10.2-18.7$ & $10.7-25.9$ & $1.1-19.8$ \\
\hline Carbohydrate & $53.2-75.8$ & $53.0-69.9$ & $33.9-76.0$ \\
\hline \multicolumn{4}{|l|}{$\begin{array}{l}\text { Sugar compositiong/100 g } \\
\text { carbohydrate }\end{array}$} \\
\hline 3,6-Anhydrogalactose & $28.9-43.5$ & & \\
\hline Arabinose & & $0.0-0.8$ & \\
\hline Fucose & & $0.2-0.4$ & $4.2-8.5$ \\
\hline Galactose & $33.6-57.0$ & $7.2-8.5$ & \\
\hline Glucose & $21.8-40.6$ & $0.2-25.4$ & $24.5-62.2$ \\
\hline Mannitol & & & $11.2-37.9$ \\
\hline Mannose & $0.0-0.8$ & $0.0-4.2$ & \\
\hline Rhamnose & $0.0-0.4$ & $22.2-51.1$ & \\
\hline Ribose & & $0.1-2.7$ & \\
\hline Uronic acids & & $25.9-28.8$ & $20.8-41.6$ \\
\hline Xylose & $0.0-1.3$ & $5.6-14.4$ & $6.0-12.0$ \\
\hline References & $\begin{array}{l}\text { (Jeong et al., 2011; Kim et al., 2015; Malihan } \\
\text { et al., 2014; Park et al., 2011; Sukwong et al., } \\
\text { 2018) }\end{array}$ & $\begin{array}{l}\text { (Mhatre et al., 2018; Peña-Rodríguez et al., } \\
\text { 2011b; Robin et al., 2017; Tabarsa et al., } \\
\text { 2012) }\end{array}$ & $\begin{array}{l}\text { (Marinho et al., 2015; Møller et al., } \\
\text { 2016; Sharma et al., 2018) }\end{array}$ \\
\hline
\end{tabular}

2018). Kelp is a traditional term used to designate a particular group of brown seaweeds belonging to the Laminariales that includes Laminaria, Alaria and Saccharina sp. Brown seaweeds' composition is highly complex and has a strong seasonal character. This complexity leads to the presence of many different minor interesting compounds, including polar lipids, phenolic compounds, pigments, essential minerals or proteins (Rey et al., 2019). Brown seaweeds have a very heterogeneous and unique carbohydrates' composition (Manns et al., 2014). Carbohydrates are usually present in high amounts (up to 65\%), making them interesting feedstock for biofuel applications. Typical structural cell wall polysaccharides include alginates and/or fucoidans. Cellulose is also a structural polysaccharide commonly present. Laminaran is a storage polysaccharide that is found only in brown seaweeds. Alginates (or uronates) are the most abundant polysaccharides in the structure of marine brown seaweeds and can represent up to $50 \%$ of the total carbohydrate fraction (Offei et al., 2018). They provide the stability and flexibility needed to resist currents in aquatic environments (Barbot et al., 2016). Alginates (mainly calcium, sodium and potassium salts of alginic acid) are mainly composed of $\beta$-D mannuronic acid (M) and $\alpha$-Lguluronic acid (G) units forming heteropolymeric (with $M$ and $G$ ) or homopolymeric blocks (only M or only $\mathrm{G}$ ) bound with $\beta$ - $(1,4)$ glycosidic bonds (or $\alpha-(1,4)$ in the case of G blocks) (Gomez et al., 2009). Fucoidans' structure differs with the type of seaweed. They are mainly composed of L-fucose and sulfates, albeit many other monosaccharides may be present (mannose, glucose, galactose, xylose, uronic acids or rhamnose). Despite not being completely known their role, they may have a protective effect against drying (Cardoso et al., 2014) and they have been extensively studied for its bioactive potential. Glucose is the main sugar monomer of laminarins. They have two types of chains: one is mainly composed of glucose, and the other has a glucose backbone with mannitol residues attached to the reducing terminals. It can go up to $35 \%$ (dry weight) of the seaweed (Jung et al., 2013).

\section{Pretreatments for seaweed fractionation}

Due to the complex composition of seaweeds, one of the crucial steps in macroalgae biorefinery is the pretreatment, as a way to separate the biomass into their main fractions, releasing the polysaccharides and enhancing the hydrolysate's accessibility for microorganisms and enzymes. Therefore, the pretreatment plays a key role in the seaweed biorefinery. Moreover, seaweeds have little or no lignin, consequently the requirements for the pretreatments are less severe than for other biomasses, resulting in shorter reaction times, lower temperature or lower reagent concentrations compared to lignocellulosic biomass (Dave et al., 2019; Ganesh Saratale et al., 2018; Thompson et al., 2019).

Seaweeds can be subjected to different type of pretreatments to increase their susceptibility for the production of biofuels and/or chemicals. The main pretreatments used for processing of seaweed can be classified according to:

(i) The type of pretreatment: physical, physicochemical (hydrothermal treatment or supercritical $\mathrm{CO}_{2}$ ), chemical (dilute acid, deep eutectic solvents or ionic liquids) or biological (enzymatic or microbiological).

(ii) Emerging or traditional pretreatment.

(iii) Green pretreatments.

A possible classification, according to these three criteria, is presented in Table 2 (Dave et al., 2019; Hassan et al., 2018; Tu and Hallett, 2019).

Hereunder, recent advances in the processing of seaweed oriented to the polysaccharide extraction are detailed. In addition, the pretreatments employed for the obtainment of other compounds (such as phenolic compounds, proteins, pigments) which cannot be used in the

Table 2

Classification of seaweed pretreatments.

\begin{tabular}{lll}
\hline Type of pretreatment & $\begin{array}{l}\text { Emerging } \\
\text { technology }\end{array}$ & Green pretreatment \\
\hline $\begin{array}{l}\text { Physical or mechanical } \\
\text { Milling and extrusion }\end{array}$ & \\
Microwave & + & + \\
Sonication & + & \\
Electric fields & + & \\
Physicochemical & & + \\
Hydrothermal & & + \\
Pressurized liquid extraction & & \\
$\quad$ (organic solvents) & & + \\
Supercritical fluids & & \\
Chemical & & + \\
Dilute acid & & + \\
Ionic liquids & + & + \\
Deep Eutectic Solvents & + & \\
Biological & & \\
Enzymatic & & \\
\end{tabular}


Table 3

Main products derived from the pretreatments.

\begin{tabular}{|c|c|c|c|c|c|}
\hline Raw material & Pretreatment & Operational conditions & Main products & Yield* & Refs. \\
\hline \multicolumn{6}{|l|}{ Green seaweed } \\
\hline Ulva sp. & Dilute acid & $\begin{array}{l}\mathrm{H}_{2} \mathrm{SO}_{4}(0.6 \%) \text { Temperature }\left(120{ }^{\circ} \mathrm{C}\right) \text {, time } \\
(20 \mathrm{~min})\end{array}$ & $\begin{array}{l}\text { Carbon (reducing sugars) for thermostable } \\
\text { cellulases, using a fungus (Aspergillus } \\
\text { fumigatus) }\end{array}$ & $12 \%$ & $\begin{array}{l}\text { Ben Yahmed et al., } \\
2018\end{array}$ \\
\hline Ulva rigida & Ionic liquids & $\begin{array}{l}\text { SIL, DIL, LVIL, solid loading (10 wt } \%) \\
\text { Temperature }\left(100-160{ }^{\circ} \mathrm{C}\right) \text {, time }(6 \mathrm{~h})\end{array}$ & $\begin{array}{l}\text { Carbohydrates for the production of } \\
\text { platform chemicals or biofuels }\end{array}$ & $79 \%$ & $\begin{array}{l}\text { Pezoa-Conte et al., } \\
2015\end{array}$ \\
\hline \multicolumn{6}{|l|}{ Red seaweed } \\
\hline Gelidium amansii & Ultrasonication & $\begin{array}{l}\text { US with diluted } \mathrm{HCl} \text { Power }(30 \mathrm{kHz}) \text {, amplitude } \\
(40 \%) . \text { Time }(30 \mathrm{~min})\end{array}$ & Agarose & $4.8 \%$ & Chew et al., 2018b \\
\hline Kappahycus alvarezii & Ionic liquids & Assisted with subcritical water extraction & $\kappa$-carrageenan & $79 \%$ & Gereniu et al., 2018 \\
\hline Kappahycus alvarezii & Deep eutectic solvents & $\begin{array}{l}\text { ChCl:Urea, Ch:Ethylene:Glycol, ChCl:Glycerol } \\
\text { Temperature }\left(85-95^{\circ} \mathrm{C}\right) \text {, time }(1 \mathrm{~h})\end{array}$ & $\kappa$-carrageenan & $54 \%$ & Das et al., 2016 \\
\hline \multicolumn{6}{|l|}{ Brown seaweed } \\
\hline Ascophyllum nodosum & Irradiation & $\begin{array}{l}\text { US with } \mathrm{HCl}(0.03 \mathrm{M}) \text {, Power }(750 \mathrm{~W}) \text {, frequency } \\
(20 \mathrm{kHz}) \text { Amplitude }(114 \mu \mathrm{m}) \text {, Time }(25 \mathrm{~min})\end{array}$ & $\begin{array}{l}\text { Phenolics Fucose } \\
\text { Uronic Acids }\end{array}$ & $\begin{array}{l}14 \% \\
8.7 \% \\
12 \%\end{array}$ & Kadam et al., 2015 \\
\hline Fucus spiralis & $\begin{array}{l}\text { Pressurized Liquid } \\
\text { Extraction }\end{array}$ & $\begin{array}{l}\text { Acetone/water }(80: 20) \\
\text { Temperature }\left(60^{\circ} \mathrm{C}\right) \text {, pressure }(1000 \mathrm{psi})\end{array}$ & Phenolic compounds & $20 \%$ & Tierney et al., 2013 \\
\hline Fucus vesiculosus & Hydrothermal & Temperature $\left(180{ }^{\circ} \mathrm{C}\right)$, time $(20 \mathrm{~min})$ & Fucoidan & $18 \%$ & $\begin{array}{l}\text { Rodríguez-Jasso } \\
\text { et al., } 2013\end{array}$ \\
\hline Himanthalia elongata & $\begin{array}{l}\text { Pressurized Liquid } \\
\text { Extraction }\end{array}$ & $\begin{array}{l}\text { Hexane, ethanol, water } \\
\text { Temperature }\left(100^{\circ} \mathrm{C}\right) \text {, time }(20 \mathrm{~min})\end{array}$ & Liquors with antioxidant bioactivity & $7.3 \%$ & Plaza et al., 2010b \\
\hline Laminaria ochroleuca & Hydrothermal & Temperature $\left(160{ }^{\circ} \mathrm{C}\right)$ & Fucoidan & $17 \%$ & $\begin{array}{l}\text { Flórez-Fernández } \\
\text { et al., } 2019\end{array}$ \\
\hline Saccharina japonica & Ionic liquids & $\begin{array}{l}\text { Imidazolium-based ILs } \\
\text { Assisted with subcritical water extraction } \\
\text { Temperature }\left(175^{\circ} \mathrm{C}\right)\end{array}$ & Phenolic compounds & $5.9 \%$ & Vo Dinh et al., 2018 \\
\hline Sargassum muticum & Hydrothermal & Temperature $\left(170^{\circ} \mathrm{C}\right)$ & Fucoidan & $85 \%$ & Balboa et al.,2013 \\
\hline
\end{tabular}

US: Ultrasonication. SIL: Switchable ionic liquid (DBU-MEA-SO ${ }_{2}$ ). DIL: Distillable ionic liquid (TMG propionate). LVIL: protonated 1,8-diazabicyclo-[5.4.0]-undec-7ene 2,2,3,3,4,4,5,5-octafluoro-1-pentoxide. MW: microwave

*Yields measured in $g$ of component per $g$ of component in the raw material, were calculated from articles data.

biofuel production have also been considered, since the remaining solid after the pretreatment step is mainly composed by cellulose or other oligomers that may be employed for biofuel production. Furthermore, most of the authors evaluate and optimize the pretreatment to extract a single value-added product (such as hydrocolloids, proteins, bioactive compounds, pigments, sugars for biofuel production, etc.) from the whole seaweed. In this sense, Table 3 gathers the most recent works published in the literature including the pretreatment used and the main product produced.

\subsection{Previous steps}

Prior to pretreatment, some steps are proposed to prepare the seaweeds (Dave et al., 2019; Maneein et al., 2018; Michalak, 2018; Rigdon et al., 2013), namely:

(i) Washing/cleaning: removing undesired objects such as stones, sand, salts, other seaweeds, detritus material or garbage. It is especially important in the case of seaweed collected from nature.

(ii) Drying or dewatering: to make the seaweed optimal for the conversion procedure, which increases stability while decreasing the volume during storage and processing. The drying process may be carried out by a first step of mechanical dewatering, followed by a sun-drying process or by the use of drying facilities (as greenhouse or hot air oven) to get moisture values between 20 and $30 \%$.

(iii) Chopping and/or milling to diminish the particle size of the macroalgae to values in the order of millimeters, increasing the surface area.

Occasionally, these steps, especially milling, can be considered as physical or mechanical pretreatments. However, they are usually necessary steps before the processing or preparation stages for most type of seaweeds biorefinery schemes and, generally, these preparation seaweed steps have a small effect in the improvement of the process.
Regarding washing, this has not a clear effect in biofuels production (and may even remove water soluble polysaccharides, decreasing the final amount of biofuel), and its use implies the need to treat high amounts of downstream water from the washing step. However, it may be needed also to remove salts that can be inhibitory in posterior fermentation stages. On the other hand, milling is an essential step in order to reduce the particle size of macroalgae, similarly to the lignocellulosic biomass pre-processing.

\subsection{Physical pretreatments}

\subsubsection{Milling and extrusion}

Milling and extrusion are considered physical pretreatments of biomass that work by reducing the particle size or breaking the structures, allowing for an increased accessibility in posterior enzymatic processes with low production of inhibitory compounds and by-products and capacity of operating at high solid loadings (Hassan et al., 2018; Sun et al., 2016). In fact, these pretreatments were used in the production of biofuels from seaweed (Amamou et al., 2018; Montingelli et al., 2016). Ball milling was evaluated as pretreatment of Laminaria spp. to enhance bioconversion of seaweed into biogas (Montingelli et al., 2016). The effect of reduction size by two mechanical fractionation methods using milling modes (vibro-ball and centrifugal milling) was studied for the improvement of enzymatic saccharification of polysaccharides from Ulva lactuca and G. sesquipedate (Amamou et al., 2018). In general, this improvement is not very significant, hence mechanical pretreatments are combined with chemical treatments (Vanegas et al., 2014). Moreover, physical treatments were also used for the extraction of hydrocolloids such as agar. Recently, grinding combined with $\mathrm{HCl}$ treatment was studied for the extraction of agar from Gelidium amansii and their physicochemical properties were compared with extracted agar from other unconventional extraction methods (Chew et al., 2018b). 


\subsubsection{Microwave}

Microwave extraction works due to the selective absorption of microwaves on different materials: when applied to the external layer of the reactors (made of plastic, glass or porcelain) microwaves easily penetrate the material, only being absorbed when reaching the solvent or biomass, causing them to self-heat from the inside. Microwave has been used as alternative heating to thermal treatment of biomass due to the speed and selectivity of the method (Yuan and Macquarrie, 2015). Nevertheless, the microwaves are usually coupled with acid or alkali solvents or ionic liquids to increase efficiency (Li et al., 2016; Sun et al., 2016). Microwave was combined with $0.4 \mathrm{M} \mathrm{H}_{2} \mathrm{SO}_{4}$ treatment $\left(150{ }^{\circ} \mathrm{C}\right.$ for $1 \mathrm{~min}$ ) of brown seaweed in order to obtain fermentable sugars for bioethanol fermentation (Yuan and Macquarrie, 2015). In addition, microwave assisted treatment was used for the extraction of agar and other value-added compounds such as fucoxanthin (Sousa et al., 2010; Xiao et al., 2012).

\subsubsection{Ultrasonication}

Ultrasounds (high frequency sound waves in the range of $\mathrm{kHz}$ ) can disrupt the integrity of structural biomass due to the formation of small cavitation bubbles (Hassan et al., 2018). Biomass can be exposed to the ultrasounds directly, using a probe, or indirectly, using an ultrasonic bath; in the presence of several solvents and with low thermal effects, preserving heat sensitive compounds. Ultrasound assisted hydrolysis reduces the time of extraction and energy consumption and improves the efficiency of the process. Sonication has been used for glucose release from Ulva to produce bioethanol (Korzen et al., 2015). Besides the use of sonication for improvement of enzymatic saccharification of seaweed, this pretreatment has been also used for the extraction of value added compounds such as sulfated polysaccharides with antioxidant activity from green seaweed (Navya and Khora, 2017), phycobiliptotiens from Gelidium pusillum (Mittal et al., 2017) or, phenolic compounds from the brown macroalgae (Kadam et al., 2015).

\subsubsection{Electric fields}

When applied to biomass, electric fields will cause a fast and homogenous rise in its temperature due to the Joule effect, along with the possibility of membrane electroporation, in several types of treatments with different voltage ranges, operation modes (pulsed or continuous) and electrical flows (Rocha et al., 2018). Compared to conventional heating, all these technologies have a faster heat transfer, shorter reaction times, uniform heating and improved energy efficiency (Hassan et al., 2018). Pulsed electric fields have a different way of acting: very short but strong electric fields are applied to the samples with the main purpose of causing significant electroporation, without the heating effect. Combined technologies, such as pulsed ohmic heating are also possible. This technology has been recently used for the improvement of starch extraction from green macroalga Ulva ohnoi (Prabhu et al., 2019). Proteins and carbohydrates were also extracted from Ulva lactuca by pulsed electric fields (Postma et al., 2018).

\subsection{Physicochemical pretreatments}

\subsubsection{Hydrothermal pretreatment}

Hydrothermal processing is an environmentally friendly and costeffective pretreatment based on the use of liquid water at high temperatures (between $100{ }^{\circ} \mathrm{C}$ and $374{ }^{\circ} \mathrm{C}$ ) under pressure, and usually linked to the fractioning of lignocellulosic materials. Its main advantages include the possibility of operating using only water, lessening the corrosion of equipment; the simplicity of operational procedures; and improved enzymatic digestibility of cellulose (Hu et al., 2011; Ruiz et al., 2013). This pretreatment is one of the most used for the processing of seaweeds for ethanol production and bioactive extraction (del Río et al., 2019; Pérez-Larrán et al., 2019).

With the temperature increase (from $150{ }^{\circ} \mathrm{C}$ up to $300{ }^{\circ} \mathrm{C}$ ), water's ionic product also increases, allowing autoionization of water into acidic and basic ions, causing an enhancing effect on all ionic reactions (such as the hydrolysis of cellobioses), at the same time as the dielectric constant is reduced, aiding the solubilization of organic compounds (Carr et al., 2011). Besides particle size, pH and solid to liquid ratio, temperature and residence time are the most important operational values when modeling hydrothermal processes (Ruiz et al., 2013).

When evaluating the effect of hydrothermal treatment on the extraction of fucoidans from Sargassum muticum, Balboa and collaborators (2013) observed that, by increasing the temperature in the range of 150 to $250{ }^{\circ} \mathrm{C}$, the amount of solubilized products increased up to $62 \%$ for whole algal biomass and $85 \%$ for alginate-depleted product. In another study regarding brown seaweeds, Meillisa and co-workers (2015) concluded that the sugar recovery for $S$. japonica at temperatures in the range of $180{ }^{\circ} \mathrm{C}$ to $260^{\circ} \mathrm{C}$ was higher in the absence of any catalyst, in comparison with $1 \%$ formic acid. When studying the antioxidant extraction from several macroalgae samples, Plaza and collaborators (2010a) noticed that an increase from 100 to $200{ }^{\circ} \mathrm{C}$ lead to and increment in extraction yield (up to a five-fold increase), with a beneficial effect on the content of phenols and sugars in the extracts as well as its antioxidant capacity. Regarding the brown seaweed Fucus vesiculosus, (Rodríguez-Jasso et al., 2013) proved that autohydrolysis using distilled water was capable of extracting sugars in all runs performed (temperatures ranged from $160{ }^{\circ} \mathrm{C}$ to $200{ }^{\circ} \mathrm{C}$ and reaction time from 10 to $30 \mathrm{~min}$ ).

Using a non-isothermal autohydrolysis with temperatures ranging from $120{ }^{\circ} \mathrm{C}$ to $220{ }^{\circ} \mathrm{C}$, Cernadas and co-workers (2019) studied the fractioning of Himanthalia elongata. Even though the maximum extraction yields were observed at $180{ }^{\circ} \mathrm{C}$ (with a solubilization of $70 \%$ initial dry weight), $160{ }^{\circ} \mathrm{C}$ was the optimal condition for fucoidan extraction and the liquor obtained at $220^{\circ} \mathrm{C}$ was the one that showed the most anti-tumoral activity. On a similar study regarding Laminaria ochroleuca, Flórez-Fernández and collaborators (2019) determined that, although $220^{\circ} \mathrm{C}$ was the optimal temperature for maximizing the extraction yield, with maximal sulphate, phenolic, protein content and significant antioxidant capacity, $160{ }^{\circ} \mathrm{C}$ was the ideal operational condition for fucoidan extraction. These results prove, once again, that the choice of operational conditions depends not only on the biomass, but also on the target final product.

\subsubsection{Supercritical fluids}

Supercritical fluids (such as $\mathrm{CO}_{2}$ ) are referred to a gas that is compressed at temperature above its critical point to a liquid like density. There is a lack of studies oriented to polysaccharide extraction and/or biofuels production using this pretreatment. By analogy with lignocellulosic biomass, supercritical fluid extraction could be applied as previous step to polysaccharide recovery, in order to obtain value added bioactive compounds (Alvira et al., 2010). In fact, $\mathrm{CO}_{2}$ supercritical has been used for the extraction of high value-added compounds such as antioxidants from seaweeds (Crampon et al., 2011).

\subsubsection{Pressurized liquid extraction (organic solvents)}

Pressurized Liquid Extraction (also known as pressurized solvent extraction, accelerated solvent extraction and enhanced solvent extraction) is a green technology that involves using liquid solvents at elevated temperature and pressure for the recovery of bioactive components from plants and foods (Mustafa and Turner, 2011). The main difference with hydrothermal treatment is that hydrothermal treatment is used for the improvement of saccharification of polysaccharide and to obtain polysaccharides as oligosaccharides in the liquid phase. Furthermore, pressures used are generally higher, mainly to guaranty that all solvent is in the liquid phase. In pressurized liquid extraction, water is also evaluated as solvent for extraction purposes (in this particular case, it is also called sub-critical water extraction). However, other solvents (usually organic solvents) or/and mixtures of different solvents may also be considered and used for comparison with conventional organic solvents extraction. For this reason, some authors include this 
comparison.

The effect of extraction temperature (ranging from $50{ }^{\circ} \mathrm{C}$ to $200{ }^{\circ} \mathrm{C}$ ) and type of solvent (hexane, ethanol and water) on the extraction of bioactive compounds from macroalgae Himanthalia elongata using pressurized liquid extraction for $20 \mathrm{~min}$ was evaluated by Plaza and coworkers (2010a). For all temperatures tested, water was the solvent that originated higher extraction yield and, for all solvents, yield improved with temperature increase. Despite that, extracts obtained using ethanol were the ones with higher antioxidant activity (reaching $1.067 \pm 0.003 \mathrm{mmol}$ of Trolox per gram of extract at $100{ }^{\circ} \mathrm{C}$ ) and inhibition capacity (with extracts produced at $200{ }^{\circ} \mathrm{C}$ proving to be better than the reference antibiotic). On that extract, several compounds with bioactive interest such as fucosterol, palmitic, oleic, linoleic and araquidonic acids, fucoxanthin, violaxanthin, zeaxanthin and multiple chlorophylls and carotenoids were detected.

Moreover, Tierney and co-workers (2013) report that, pressurized liquid extraction with food-friendly solvents like ethanol and water does not provide any improvement to the conventional techniques regarding antioxidant-rich extracts, with the only advantages coming along with the use of acetone. Using pressurized liquid extraction in four different macroalgae (Ascophyllum nodosum, Pelvetia canaliculata, Fucus spiralis and Ulva intestinali) at $120^{\circ} \mathrm{C}$ and $1500 \mathrm{psi}$ for hot water, $100{ }^{\circ} \mathrm{C}$ and 1000 psi for a mixture of ethanol/water $80: 20$ and $60{ }^{\circ} \mathrm{C}$ and 1000 psi for a mixture of acetone/water 80:20, authors report an increase in extraction yield comparing to conventional methods for all water-based extractions. Nevertheless, the increase in phenolic content is only detected using acetone, reaching the highest discrepancy in samples of $P$. caniculata (168.82 $\pm 11.47 \mu \mathrm{g} / \mathrm{g}$ versus $68.24 \pm 3.36 \mu \mathrm{g} / \mathrm{g}$ for conventional extraction) and an absolute maximum of $204.40 \pm 9.45 \mu \mathrm{g} / \mathrm{g}$ in F. spiralis.

\subsection{Chemical pretreatments}

\subsubsection{Dilute acid pretreatment}

The use of catalysts such as acid reagent (combined with a high temperature), allows to properly and economically pretreat macroalgae. In lignocellulosic materials, the lack of complex structural components enables the breakdown of the holocellulose to simple sugars (hastening the hemicellulose solubilization), employed in subsequent steps of saccharification and fermentation (Dave et al., 2019; Ganesh Saratale et al., 2018; Thompson et al., 2019).

By comparison, this pretreatment has been also used for sugar extraction from seaweeds. Acid pretreatment has been widely investigated in literature, commonly employing concentrations of $0.1-5 \%$ $\mathrm{w} / \mathrm{v}$ of acid (sulfuric acid above all, although other possibilities are hydrochloric acid, nitric acid, sulfur dioxide or phosphoric acid) (Dave et al., 2019; El Harchi et al., 2018; Lee et al., 2013). After the pretreatment, the substrate is normally neutralized with sodium hydroxide or solid lime to eliminate fermentation inhibitors (Dave et al., 2019).

El Harchi and collaborators (2018) evaluated the dilute acid pretreatment on the green seaweed Ulva rigida in a wide range of concentrations (from 0 to $10 \% \mathrm{v} / \mathrm{v}$ ), solid loadings (5-15\% w/v) and time (30-60 min) at $121{ }^{\circ} \mathrm{C}$, employing sulfuric acid or hydrochloric acid. The results showed that the production of total reducing sugars increased when using low-medium concentrations of acid (either sulfuric or hydrochloric acid, between 2 and $5 \% \mathrm{v} / \mathrm{v}$ ) and long residence time (60 min), getting up to 60 and $30 \%$ of total reducing sugars for sulfuric and hydrochloric acid, respectively. Moreover, the utilization of higher acid concentrations led to a drop of the total reducing sugars, being likely that this fact occurred due to the degradation of simple sugars into furans, acids or other degradation compounds. Another work performed by Borines et al., (2013), employed an experimental design to evaluate Sargassum sp., at different sulfuric acid concentrations, temperatures and residence times. Something similar happened in this study, where the reducing sugars content improved with the longest residence times, whereas the temperature was not a limiting factor. On the other hand, the acid concentration of 3-5\% allowed to reach higher concentrations of both reducing sugars and glucose, with a maximum of $120 \mathrm{mg} / \mathrm{g}$ seaweed and $42 \mathrm{mg} / \mathrm{g}$ seaweed, respectively. Ge and collaborators, (2011) pretreated Laminaria japonica wastes (from industrial processes) for $0.5-1.5 \mathrm{~h}$ at $121{ }^{\circ} \mathrm{C}$ with a sulfuric acid concentration between 0 and $1 \%$. In this case, maximum glucose concentration was achieved at $0.1 \%, 121{ }^{\circ} \mathrm{C}, 1.0 \mathrm{~h}$ at $277.5 \mathrm{mg} / \mathrm{g}$. It was noticed that for sulfuric acid concentrations higher than $0.1 \%$, the glucose decreased, until $156-189 \mathrm{mg} / \mathrm{g}$ at the concentration of $1 \%$. Similarly, Eucheuma cottonii cellulosic residue was utilized by Tan and Lee, (2015) with a dilute acid $\left(\mathrm{H}_{2} \mathrm{SO}_{4}\right)$ pretreatment, employing a concentration of $1 \%$, $120{ }^{\circ} \mathrm{C}, 30 \mathrm{~min}$ and a solid loading of $10 \% \mathrm{w} / \mathrm{v}$. After the pretreatment, the 80 and $81 \%$ of glucose was recovered, increasing the opportunity of getting higher enzymatic digestibility.

Another option would be the use of Extremely Low Acid pretreatment, employing lower concentrations than 1\%. Lee et al., (2013) noticed that using concentrations of $0.02-0.14 \%$ sulfuric acid and higher temperatures $\left(150-180{ }^{\circ} \mathrm{C}\right)$ and residence times of 5-20 min, permitted to recover the $21-32 \%$ of glucan in the solid phase. The maximum glucan content was acquired at $0.10 \%$ sulfuric acid, $170{ }^{\circ} \mathrm{C}$ and $20 \mathrm{~min}$, while temperature of $180^{\circ} \mathrm{C}$ provoked an intense decrease of the glucan content. On the contrary, Karray and co-workers (2015) used a high sulfuric acid concentration (98\%), at $100{ }^{\circ} \mathrm{C}$ for $2 \mathrm{~min}$ as an acid catalyst, obtaining $3.75 \mathrm{~g}$ reducing sugars per L. In contrast, Gelidium amansii can be used to obtain galactose, as shown by Cho et al., (2014). In this case, $\mathrm{H}_{2} \mathrm{SO}_{4} 91 \mathrm{mM}$ was employed at $121{ }^{\circ} \mathrm{C}, 45 \mathrm{~min}$ and a solid loading of $8 \% \mathrm{w} / \mathrm{v}$, resulting in $25.6 \mathrm{~g}$ galactose/L of hydrolysate.

\subsubsection{Ionic liquid pretreatment (IL)}

Last years, Ionic Liquids (ILs) have attracted much attention as greener substitute to organic solvents for the sustainable processing of seaweed biomass due to interesting physicochemical features (namely, strong miscibility with aqueous solutions, negligible vapor pressure, high thermal and electrochemical stability and wide solvating range (Vo Dinh et al., 2018). ILs have been successfully used for the solubilization of cellulose and chitin from lignocellulosic biomass and crustaceous wastes shells, respectively (Kerton et al., 2013). From this perspective, the extraction of polysaccharides from seaweeds in ILs is envisaged (Das et al., 2016).

In fact, ILs have been evaluated as alternative to conventional methods for the extraction of hydrocolloids (such as agars, alginates and carrageenan) (Chew et al., 2018a). The ionic liquid 1-ethyl-3-methylinmidazolium acetate $[\mathrm{Emim}][\mathrm{OAc}]$ has been used in the pretreatment of Gracilaria dura at $80{ }^{\circ} \mathrm{C}$ for $120 \mathrm{~min}$ by microwave irradiation for the $39 \mathrm{wt} \%$ of good-quality agarose extraction (Trivedi and Kumar, 2014). Gereniu and co-workers (2018) reported a maximal extraction of $78.75 \%$ k-carrageenan using subcritical water $\left(150{ }^{\circ} \mathrm{C}\right.$ and $5 \mathrm{MPa}$ ) catalyzed by $1 \%$ of 1-butyl-3-methylimidazolium acetate (BMIMAc). Recently, ILs combined with supercritical water extraction has been used for the recovery of bioactive compounds as phenolic compounds (Vo Dinh et al., 2018). Vieira and co-workers (2018) also evaluated the surface-active ionic liquid to recover carotenoids from Sargassum muticum.

Moreover, ILs were used as pretreatment to improve the enzymatic saccharification of agarose for galactose and anhydro-galactose production from Gelidium amansii (Weldemhret et al., 2019) and for the enzymatic saccharification of cellulose from alginate industrial waste obtained from Laminaria japonica (Wang et al., 2013). ILs pretreatment using 1-hexylpiridinium chloride ([Hpy] [Cl]) was also combined with a first step of peracetic acid pretreatment $\left(80{ }^{\circ} \mathrm{C}\right.$ for $\left.3 \mathrm{~h}\right)$ to solubilise saccharides and to improve the enzymatic sacacharification of waste biomass from carrageenan industry (Uju et al., 2015).

\subsubsection{Deep eutectic solvents (DES)}

More recently, deep eutectic solvents (as Choline chloride urea) have emerged as substitute to conventional imidazolium-based ionic 
liquids, since they are considered much cheaper, safer and easier to prepare than ILs (Zdanowicz et al., 2018). Nevertheless, DES for the biopolymer extraction from seaweed is not extensively explored so far (Das et al., 2016). Few works reported the use of DES for processing of macroalgae or residues from seaweed processing (Das et al., 2016; Saravana et al., 2018), where $60.25 \%$ of K-carrageenan was extracted from $K$. alvarezii using $10 \%$ of hydrated Choline-Cholirede-Glycerol 1:2 (Das et al., 2016).

\subsection{Biological pretreatment}

Biological pretreatment consists of the use of biological microorganisms (such as fungi or bacteria) and/or enzymes (enzyme-assisted extraction) for the degradation of any component of the biomass (Thompson et al., 2019). These pretreatments are cost-effective, ecologically friendly and can be used aerobically or anaerobically (TapiaTussell et al., 2018). Regarding the enzymes, they are chosen depending on the main components of biomass, such as cellulose, hemicelluloses, glycoproteins, pectin or even lignin. The most employed microorganisms for the production of enzymes are fungi, specially the white rot fungi (Trametes sp.), which produces the enzymes manganese peroxidase, lignin peroxidase and laccase, that can efficiently degrade the lignin (Tapia-Tussell et al., 2018; Thompson et al., 2019). Other promising candidates for the production of enzymes are Trichoderma, Penicillium, Fusarium, Phanerochaete, Humicola and Schizophillum (Soliman et al., 2018). Some studies, explored the use of biological pretreatment on macroalgae. Tapia-Tussell et al., (2018) applied the Bm-2 strain of Trametes hirsuta, resulting in a degradation of fibers and the creation of gaps on the macroalgae surface. Although good results can be obtained, the use of biological pretreatments usually implies long-time pretreatments and/or its combination with other pretreatments, especially chemical pretreatments with dilute-acid or mild-alkali hydrolysis (Soliman et al., 2018; Thompson et al., 2019).

\section{Saccharification of seaweed for production of fermentable sugars}

The hydrolysis of seaweed polysaccharides to monosaccharides is carried out by chemical or enzymatic methods. Despite recent advances in the processing of seaweed biomass, there are lack of studies in an effective and environmentally friendly alternative to acid hydrolysis to obtain monosaccharides. Recently, Yun and co-workers (2016) approached the main pretreatments used (namely, hydrothermal treatment, chemical treatment, microwave-assisted extraction) for the improvement of saccharification of red macroalgae to produce fermentable sugars. The authors identified a lack of established methods for an effective saccharification system.

The most used method for the saccharification of seaweed polysaccharides is based on chemical catalysis using mineral acids such as sulfuric, acetic, chloride, and acetic acid (Dave et al., 2019). Acid hydrolysis of macroalgae can be used as pretreatment to obtain directly high concentration of fermentable monosaccharides in short time. Nevertheless, these pretreatments require harsh reaction conditions that lead to the production of degradation compounds such as hydroxymethylfurfural (HMF), inhibitor of fermentation processes. Moreover, the use of acid catalysts causes environmental problems (such as toxicity, handling of neutralization sludge) and costly detoxification processes are required.

Therefore, the use of specific enzymes to obtain fermentable sugars emerges as a sustainable and greener alternative to chemical hydrolysis. The enzymatic saccharification is applied after a previous treatment of marine biomass. Table 4 shows operational conditions of typical pretreatments used to improve the enzymatic saccharification of seaweed and the main results obtained (sugar concentration and sugar yield). In comparison to lignocellulosic substrates, a wide range of enzymes are required in these biomasses, due to varied spectrum of polysaccharides depending of specie. Among advantages of enzymatic hydrolysis are included: i) low input amount of acid and alkaline catalysts and ii) low energy consumption.

Besides polysaccharides such as starch and cellulose (already exploited from lignocellulosic biomass), the most interesting seaweed polysaccharides to obtain fermentable sugars are $\beta$-glucans (such as laminarin, and cellulose) and galactans (such as agarose and carrageenan), since alginate is composed by units of uronic acids ( $\alpha$-L-guluronate and $\beta$-D-mannuronate) that are not fermentable by common microorganisms used for ethanol production such as the yeast Saccharomyces cerevisiae or the bacteria Escherichia coli and Zymomonas mobilis.

For the hydrolysis of laminarin four enzymes are necessary: namely, endo- $\beta(1 \rightarrow 6)$ glucanases (EC 3.2.1.75) that hydrolysed the branched chains, endo $\beta(1 \rightarrow 3)$ glucanases (EC 3.2.1.39) and exo- $\beta(1 \rightarrow 3)$ glucanases (EC 3.2.1.58), able to degrade linear laminarin into laminoritriose and laminaribiose, and $\beta$-glucosidases (EC 3.2.1.21) that lyse these laminarin oligosaccharides into glucose (Al Abdallah et al., 2016). Kim and co-workers (2018) reported the saccharification of laminarin with a single enzyme. In this work, a novel $\beta$-glucosidase enzyme (Bg11B) from marine bacterium (Sccharophagus degradans, 2-40T) was cloned and expressed in E. coli to catalyze the laminarin to produce glucose with a high conversion yield of $75 \%$.

On the other hand, for the saccharification of agarose to obtain galactose, $\alpha$-agarases (EC 3.2.1.158) and $\beta$-agarases (EC 3.2.1.81) are needed to hydrolyze the linkages of agarose $\alpha-1,3$ and $\beta-1,4$ and produce neoagarobiose and agarobiose. These sugars can be hydrolyzed to obtain D-galactose and anhydro-L-galactose by an $\beta$-agarobiose hydrolase and $\alpha$-neoagarobiose hydrolase, respectively (Weldemhret et al., 2019). Due to poor water solubility of agarose, the enzymatic saccharification of this polysaccharaide is not completely efficient without a previous chemical treatment (also known as chemical liquefaction) that yields soluble agaraoligosaccharides, more susceptible to enzymatic hydrolysis (Al Abdallah et al., 2016; Kim et al., 2012). In the study carried out by Kim and co-workers (2012), mild chemical liquefaction with acetic acid followed by enzymatic saccharification using a neoagarobiose hydrolase was proposed with a conversion of agarose into monosaccharides of $79 \%$. An interesting work was published by Weldemhret and collaborators (2019), in which the genes aga2, agaA7, aga50D, and ahgI were expressed in E. coli to obtain an enzymatic cocktail (composed by $\beta$-agarase I, $\beta$-agarase II and $\alpha$ -neoagarobiose), used for the effective saccharification of ionic liquids pretreated Gelidium amansii.

Carrageenan polysaccharide is a sulfated linear galactan that comprises D-galactose residues united by linkages of $\alpha-1,2$ and $\beta-1,4$ glycosidic bonds. The enzymatic saccharification of carrageenan is not widely approached, since carrageenolytic enzymes are not common. To date, limited number of enzymes have been related to carrageenan depolymerisation (Kang et al., 2014). Some marine bacteria (such as Pseudoalteromonas carrageenovora) have been used as sources of these enzymes (Chauhan and Saxena, 2016). On the other hand, a commercial $\alpha$-amylase was used for the saccharification of carrageenan yielding $92.6 \%(\mathrm{w} / \mathrm{w})$ of carrageenan derived-oligosaccharides and $1 \%(\mathrm{w} / \mathrm{w})$ of galactose (Wu et al., 2010).

Available commercial enzymes (namely, Celluclast 1.5 L, Lactozym, Spirizyme, Viscozyme and AMG-glucoamylase) have been evaluated for the saccharification of non-cellulose polysaccharides yielding low concentration of monosaccharides sugars (Huang et al., 2014). Considering the lack of commercial enzymes for an effective saccharification of the whole seaweed polysaccharides, residues generated from the hydrocolloid extraction industry, mainly composed by cellulose, arise as an interesting substrate for bioethanol production. In this sense, floating residue (obtained from the alginate extraction process) was used for the saccharification of cellulose to obtain fermentable sugars using a sulfuric acid pretreatment followed by enzymatic hydrolysis, achieving a maximal glucose release of $277.5 \mathrm{mg} / \mathrm{g}$ of floating residue 
Table 4

Seaweed pretreatments, conditions, raw material and chief results.

\begin{tabular}{|c|c|c|c|c|c|}
\hline & Pretreatment & Conditions pretreatment & Enzymatic concentr. & Enzymatic yield & References \\
\hline \multicolumn{6}{|l|}{ Green seaweeds } \\
\hline Chaetomorpha linum & Dilute acid & $\begin{array}{l}\mathrm{NaOH}(3 \%) \\
\mathrm{H}_{2} \mathrm{SO}_{4}(0.6 \%) \\
\text { Temperature }\left(120{ }^{\circ} \mathrm{C}\right) \\
\text { Time }(20 \mathrm{~min})\end{array}$ & 5.8-11.2 g glucose/L & - & $\begin{array}{l}\text { Ben Yahmed et al., } \\
2016\end{array}$ \\
\hline Zostera marina & Hydrothermal & $\begin{array}{l}\text { Temperatures }\left(160-180{ }^{\circ} \mathrm{C}\right) \\
\text { Time }(60-300 \mathrm{~s}) \\
\text { Oxalic acid }(0-2 \mathrm{wt} \%)\end{array}$ & - & $30.1-52.9 \%$ glucose & Viola et al., 2008 \\
\hline \multicolumn{6}{|l|}{ Red seaweeds } \\
\hline Gelidium amansii & Dilute acid & $\begin{array}{l}\mathrm{H}_{2} \mathrm{SO}_{4}(91 \mathrm{mM}) \\
\text { Temperature }\left(121{ }^{\circ} \mathrm{C}\right) \\
\text { Time }(45 \mathrm{~min}) \\
\text { Solid loading } 8 \%(\mathrm{w} / \mathrm{v})\end{array}$ & 7.6 g glucose/L & - & Cho et al., 2014 \\
\hline Gelidium amansii & Ionic liquids & $\begin{array}{l}\text { [EMIM]Cl, [BMIM]Cl, [EMIM]Ac or } \\
\text { [BMIM]Ac } \\
\text { Temperature }\left(30-100{ }^{\circ} \mathrm{C}\right) \\
\text { Time }(1-24 \mathrm{~h})\end{array}$ & - & $33-56.5 \%$ galactose & $\begin{array}{l}\text { Weldemhret et al., } \\
2019\end{array}$ \\
\hline $\begin{array}{l}\text { Seaweed waste biomass from } \\
\text { carrageenan industry }\end{array}$ & Ionic liquids & $\begin{array}{l}\text { Paracetic acid }+[\mathrm{Hpy}][\mathrm{Cl}],[\mathrm{EMIM}][\mathrm{DEP}] \text { or } \\
[\text { EMIM }][\mathrm{OAc}]) \\
\text { Temperature }\left(80-100{ }^{\circ} \mathrm{C}\right) \\
\text { Time }(0.5-3 \mathrm{~h})\end{array}$ & - & $62-91 \%$ glucose & Uju et al., 2015 \\
\hline \multicolumn{6}{|l|}{ Brown seaweeds } \\
\hline Eucheuma cottonii cellulosic residue & Dilute acid & $\begin{array}{l}\mathrm{H}_{2} \mathrm{SO}_{4}(1 \% \mathrm{w} / \mathrm{v}) \\
\text { Temperature }\left(120^{\circ} \mathrm{C}\right) \\
\text { Time }(30 \mathrm{~min}) \\
\text { Solid loading }(10 \% \mathrm{w} / \mathrm{v})\end{array}$ & - & $80.2-99.8 \%$ glucose & Tan and Lee, 2015 \\
\hline Laminaria japonica wastes & Dilute acid & $\begin{array}{l}\mathrm{H}_{2} \mathrm{SO}_{4}(0-1 \% \mathrm{w} / \mathrm{v}) \\
\text { Temperature }\left(121^{\circ} \mathrm{C}\right) \\
\text { Time }(0.5-1.5 \mathrm{~h})\end{array}$ & - & $92.5 \%$ glucose & Ge et al., 2011 \\
\hline Laminaria japonica & Dilute acid & $\begin{array}{l}\mathrm{H}_{2} \mathrm{SO}_{4}(0.02-0.14 \%) \\
\text { Temperature }\left(150-180{ }^{\circ} \mathrm{C}\right) \\
\text { Time }(5-20 \mathrm{~min})\end{array}$ & - & $83 \%$ glucose & Lee et al., 2013 \\
\hline Sargassum muticum & Hydrothermal & Temperature $\left(130-180^{\circ} \mathrm{C}\right)$ & $\begin{array}{l}\text { 6.01-8.35 g glucose/ } \\
\text { L }\end{array}$ & $89-94 \%$ glucose & del Río et al., 2019 \\
\hline Sargassum sp. & Dilute acid & $\begin{array}{l}\mathrm{H}_{2} \mathrm{SO}_{4}(1-5 \% \mathrm{w} / \mathrm{v}) \\
\text { Temperature }\left(115-126{ }^{\circ} \mathrm{C}\right) \\
\text { Time }(0.5-1.5 \mathrm{~h}) \\
\text { Solid loading } 10 \%(\mathrm{w} / \mathrm{w})\end{array}$ & $\begin{array}{l}2.55-4.16 \text { g glucose/ } \\
\mathrm{L}\end{array}$ & - & Borines et al., 2013 \\
\hline
\end{tabular}

EMIM: 1-Ethyl-3-methylimidazolium; BMIM: 1-n-butyl-3-methylimidazolium; Hpy: hexylpyridinium; AHG: 3, 6-Anhydro-L-Galactose.

(Ge et al., 2011). Moreover, the seaweed solid waste obtained from kcarregeenan extraction industry (containing $64 \%$ of cellulose) was hydrolyzed by commercial cellulases achieving $>90 \%$ of conversion (Tan and Lee, 2014).

\section{Biofuel production}

Nowadays, the large-scale production of biofuels from seaweed are not economically viable, but it is expected to be feasible in the near future. The most relevant biofuels produced from seaweed are ethanol, butanol, methane and biodiesel. Other biofuels include bio-oil, hydrogen and other hydrocarbon derivatives (Bharathiraja et al., 2015). Taking into account the relatively low lipid content in comparison to microalgae (Ghadiryanfar et al., 2016), diesel from macroalgae has not been considered in this review. On the other hand, liquid biofuels (such as bioethanol and biobutanol) are obtained by fermentation and methane by anaerobic digestion (Wei et al., 2013). Therefore, the necessary steps related to seaweed processing for bioethanol and biobutanol production are common and considered further.

By analogy with lignocellulosic biofuels, the same three core steps are necessary to obtain bioethanol or biobutanol from seaweed: i) pretreatment of biomass; ii) saccharification of polysaccharides to obtain monosaccharides and; iii) fermentation of sugars. The last two stages can be carried out separately or simultaneously, known as SHF and SSF, respectively, as happens with lignocellulosic biomass (Sirajunnisa and Surendhiran, 2016). SSF shows advantages over SHF process, such as: lower contamination due to consumption of sugars simultaneously with the biofuel production, lower osmotic stress and higher energy efficiency (Jung et al., 2013).

Although the most mature biochemical process for the obtainment of liquid biofuels is the ethanol fermentation, biobutanol fermentation is well-known because of different biobutanol benefits, such as better blending to gasoline, low vapor pressure or higher specific energy content (29 MJ/L, compared with $16 \mathrm{MJ} / \mathrm{L}$ for the ethanol), however it has a lower yield compared to the production of ethanol under comparable conditions (Hou et al., 2017). In addition, acetone-butanolethanol (ABE) fermentations at pilot and industrial scales have been successfully carried out (Huesemann et al., 2012). The biobutanol production is performed via the ABE fermentation pathway, from an extensive diversity of sugars, both hexoses and pentoses (Hou et al., 2017; van der Wal et al., 2013). The bacteria Clostridium is the most commonly employed in this process, standing out the species: Clostridium acetobutylicum, Clostridium beijerinckii and Clostridium aurantibutyricum (Huesemann et al., 2012; van der Wal et al., 2013). The process is separated in two phases, acidogenic and solventogenic. The former occurs during the grow of cells and the conversion of carbohydrates to acids and gas, such as butyrate (butyric acid) and acetate (acetic acid), carbon dioxide and hydrogen. The latter comprehend a stationary phase where the acids, originated in the previous step, are transformed into organic solvents (ABE) (Hou et al., 2017). The green algae Ulva lactuva, was employed by van der Wal et al., (2013) to produce $\mathrm{ABE}$ after a hot-water treatment. In this case, Clostridium acetobutylicum and Clostridium beijerinckii were used with no nutrient supplementation, achieving an ABE yield of $0.35 \mathrm{~g} / \mathrm{g}$ sugar consumed. Similarly, Hou et al., (2017) employed Laminaria digitata and Clostridium beijerinckii, reaching a butanol yield of $0.42 \mathrm{~g} /$ substrates 
Table 5

Fermentation results of seaweed hydrolysates (after pretreatment). Pretreatment, method, strains and main results.

\begin{tabular}{|c|c|c|c|c|c|c|}
\hline & Pretreatment & Method & Microbial species & Ethanol conc. & Ethanol yield & Refs. \\
\hline \multicolumn{7}{|l|}{ Green seaweed } \\
\hline Chaetomorpha linum & Milling & SSF & S. cerevisiae ATCC 96,581 & - & $44 \mathrm{~g} / 100 \mathrm{~g} \mathrm{C} 6$ & Schultz-Jensen et al., 2013 \\
\hline Chaetomorpha linum & Dilute acid & - & S. cerevisiae & - & $9.3 \mathrm{~g} / 100 \mathrm{~g} \mathrm{RM}$ & Ben Yahmed et al., 2016 \\
\hline Chaetomorpha linum & Hydrothermal & SSF & S. cerevisiae ATCC 96,581 & - & $39-44$ g /100 g C6 & Schultz-Jensen et al., 2013 \\
\hline Chaetomorpha linum & Hydrothermal & SSF & S. cerevisiae ATCC 96,581 & - & $38 \mathrm{~g} / 100 \mathrm{~g} \mathrm{C6}$ & Schultz-Jensen et al., 2013 \\
\hline Ulva rigida & Dilute acid & - & Pachysolen tannophilus & - & $9.2-12 \mathrm{~g} / 100 \mathrm{~g} \mathrm{RM}$ & El Harchi et al., 2018 \\
\hline \multirow[t]{2}{*}{ Zostera marina } & Hydrothermal & SHF & S. cerevisiae (Sigma, type II) & - & $70 \%$ & Viola et al., 2008 \\
\hline & & SSF & & & $67 \%$ & \\
\hline \multicolumn{7}{|l|}{ Red seaweed } \\
\hline Eucheuma cottonii cellulosic residue & Dilute acid & SSF & S. cerevisiae YSC2, type II & $15-27 \mathrm{~g} / \mathrm{L}$ & $50-80 \%$ & Tan and Lee, 2015 \\
\hline \multirow[t]{3}{*}{ Gelidium amansii } & Hydrothermal & SHF & S. cerevisiae KCTC 7906 & $3.33 \mathrm{~g} / \mathrm{L}$ & $74.7 \%$ & Kim et al., 2015 \\
\hline & & SSF & & $3.78 \mathrm{~g} / \mathrm{L}$ & $84.9 \%$ & \\
\hline & Dilute acid & SHF & S. cerevisiae КССМ1129 & $6.9-14.6 \mathrm{~g} / \mathrm{L}$ & & \\
\hline \multicolumn{7}{|l|}{ Brown seaweed } \\
\hline Ascophyllum nodosum & Irradiation (MW) & - & S. cerevisiae ATCC 200,062 & $5.57 \mathrm{~g} / \mathrm{L}$ & $60.7 \%$ & Yuan and Macquarrie, 2015 \\
\hline Floating residue from Laminaria japonica & Ionic liquids & SSF & S. cerevisiae & - & $47.8 \%$ & Wang et al., 2013 \\
\hline Laminaria japonica wastes & Dilute acid & - & S. cerevisiae & $14 \mathrm{~g} / \mathrm{L}$ & $80.8 \%$ & Ge et al., 2011 \\
\hline Sargassum muticum & Hydrothermal & SSF & S. cerevisiae (PE2) & $14.10 \mathrm{~g} / \mathrm{L}$ & $81 \%$ & del Río et al., 2019 \\
\hline Sargassum sp. & Dilute acid & SSF & S. cerevisiae & $1.13-2.49 \mathrm{~g} / \mathrm{L}$ & $65-89 \%$ & Borines et al., 2013 \\
\hline
\end{tabular}

C6: hexoses; RM: raw material. MW: microwave.

Seaweeds are important sources of carbohydrates for the production of biofuels.

Pretreatment is the key step for the development of seaweed biorefinery.

Emerging and green technologies can contribute to feasibility of seaweed biorefinery.

Wastes from hydrocolloid industry are interesting alternative for biofuels production.

consumed, with a high ABE molar ratio of 0.85 (compared with a typical value of 0.6 ).

Bioethanol is the most important liquid biofuel produced worldwide (Balat et al., 2008). Last two decades, research efforts have been devoted on bioethanol production from seaweeds (Jiang et al., 2016). Table 5 collects the most relevant results in last years on ethanol production using several pretreated seaweeds. As seen, the most common microorganism was the yeast $S$. cerevisiae. Recently, an environmentally friendly pretreatment, autohydrolysis, was used for ethanol production from invasive macroalgae Sargassum muticum by SSF, achieving $14 \mathrm{~g} / \mathrm{L}$ (del Río et al., 2019). Similar ethanol concentration was also reported from acid pretreated Gelidium amanssi by SHF (Kim et al., 2015). Regarding the most suitable pretreatment for fermentable sugars release and biofuels production, both dilute acid treatment and hydrothermal treatment followed by enzymatic saccharification showed a higher product yield (higher than $80 \%$ ) in comparison with other pretreatments (Tables 4 and 5). In this way, the use of an acidic catalysts is recommended to get higher yield and be cost-effective. However, it is not completely eco-friendly, unlike the hydrothermal pretreatment.

The main obstacle of bioethanol production from seaweed is the inability of common ethanologenic yeast and/or bacteria (as S. cerevisiae and $Z$. mobilis) to metabolize the wide-range of sugars generated from seaweed processing. Taking this into account, other yeast species (such as Bettanomyces custersi, Scheffersomyces stipites and Kluyveromyces marxianus) have been used to produce ethanol from acid hydrolysis of G. amansii, Ascophylum nodosum and Laminaria digitata, respectively (Jung et al., 2013). Recently, a phenotypic microarray technique was used to screen 25 yeast to metabolize typical monosaccharides from seaweed (Kostas et al., 2016). This study revealed the potential of three Saccharomyces spp, one Pichia spp and one Candida spp. Besides the high utilization of glucose, these strains showed high metabolic outputs in the galactose, mannitol, fucose, xylose and rhamnose consumption. The highest ethanol concentration (13 g/L) from acid treated Chondrus crispus hydrolysate was obtained using $S$. cerevisiae YPS128, showing the ability to consume the majority of available monosaccharides present in the hydrolysate. The use and engineer of robust $S$. cerevisiae strains selected for their tolerance to hydrolysate's inhibitors (Costa et al., 2017; del Río et al., 2019; Pereira et al., 2011; Romaní et al., 2015) is also recommended for effective bioethanol production.

In the fermentation of red seaweed hydrolysate, glucose causes catabolic repression in the uptake of galactose and 3,6-anhydro-L-galactose is not fermented by industrial microorganisms, achieving poor utilization of sugars from these seaweeds (Yun et al., 2016). In this sense, metabolic and evolutionary engineering strategies have been suggested to increase galactose consumption (Nguyen et al., 2017; Yun et al., 2016).

In brown seaweeds, the uronic acid (main constituent of alginate) is also not consumed by $S$. cerevisiae. On the other hand, mannitol is easily extracted from these seaweeds with a simple pressing without additional pretreatment (Van Hal et al., 2014). For ethanol production from mannitol, this sugar alcohol must be converted into fructose-6-phosphate Only some microorganisms are capable of this conversion presenting distinct pathways for that purpose (Al Abdallah et al., 2016). The development of Consolidated BioProcessing was approached in a recent study that showed the direct production of ethanol from brown algae by a thermophilic bacterium (Defluviitalea phaphyphila), achieving high ethanol yields of $0.4 \mathrm{~g} / \mathrm{g}$ mannitol, $0.44 \mathrm{~g} / \mathrm{g}$ of glucose and $0.3 \mathrm{~g} / \mathrm{g}$ of alginate ( $\mathrm{Ji}$ et al., 2016). A metabolic engineered $S$. cerevisiae for mannitol and alginate bioconversion was able to ferment $83 \%$ of theoretical sugars (including mannitol, alginate and glucose) derived from brown seaweed (Enquist-Newman et al., 2014).

In the last years, the scientific community is devoting great effort to develop seaweed as raw material for biofuels production as an alternative of non-lignocellulosic feedstock due to several advantages above described (Baghel et al., 2015). Nevertheless, the sustainability of macroalgae biofuel production is not economic feasibility, being necessary the simultaneous production of other commodities under a biorefinery concept (Sadhukhan et al., 2019).

\section{Seaweed Biorefinery: Pretreatments for an integral valorization}

Seaweed biorefinery concept (like as lignocellulose biorefinery concept) emerges due to the need of achieving sustainable growth based on a bioeconomy and circular economy with zero-waste generation. Moreover, the 17 Goals of the 2030 Agenda for Sustainable Development are focused on the use of greener and more efficient processes (Clarke et al., 2018). Therefore, the selected pretreatment for the processing of biomass should be carried out not only with the goal of recovering the maximum fractions as possible, but also to contribute for environmental sustainability. As described above, the seaweeds are 


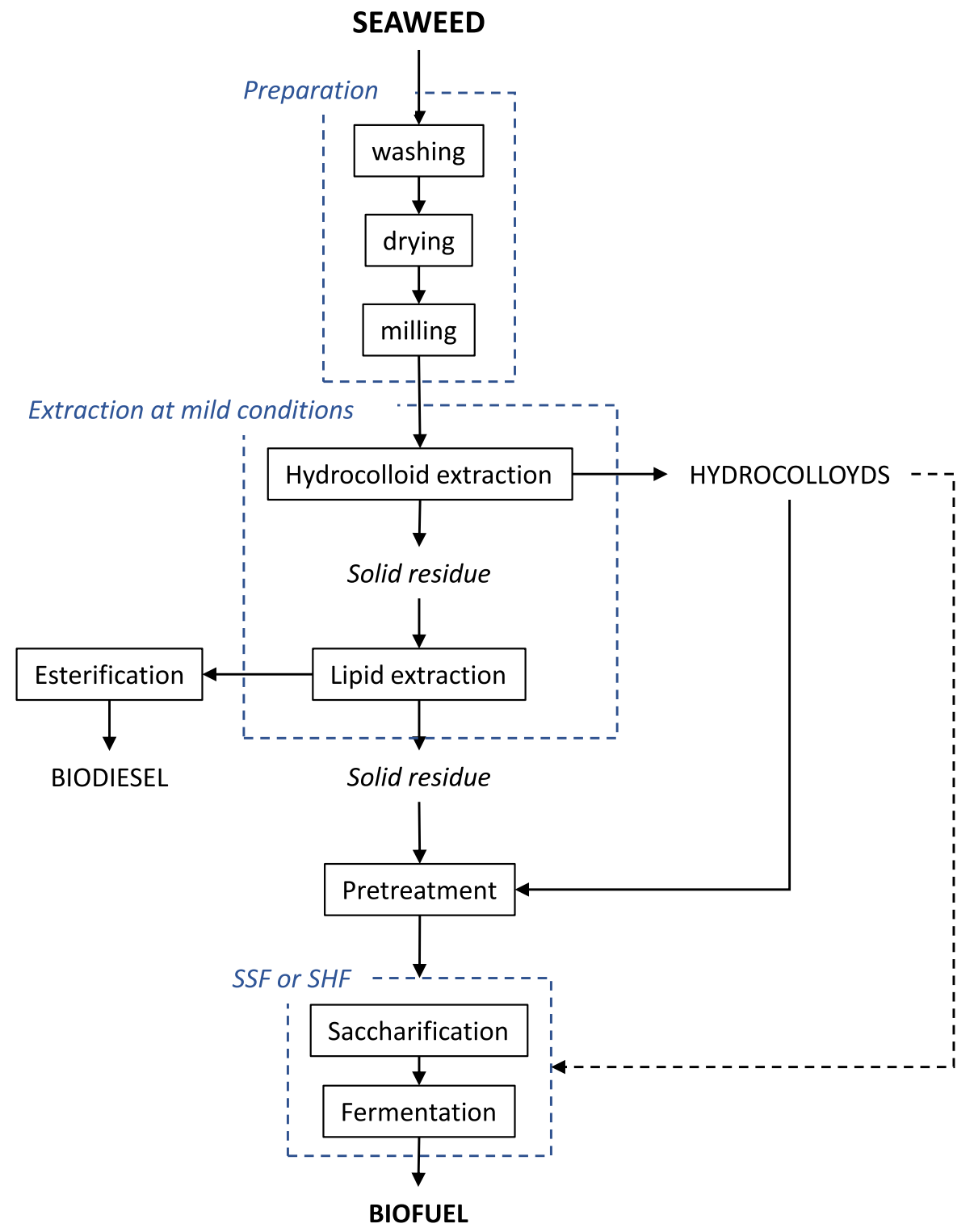

Fig. 1. Scheme of seaweed biorefinery for biofuels production.

a rich source in polysaccharides, proteins, amino acids, dietary fibers, minerals, fatty acids, natural antioxidant compounds and pigments which can be obtained/recovered by suitable fractionation process. Therefore, the challenge is to use macroalgae great potential for the production of sugars, proteins and inorganic platforms in a seaweed biorefinery systems (Sadhukhan et al., 2019). A rational processing of whole seaweed allows the development of this biorefinery based seaweed biomass, as shown in Fig. 1 (scheme of biorefinery proposed).

The use of a seaweed biorefinery cascade approach with the final residue of phycocolloids industries being used for biofuels allows the exploitation of high value seaweed compounds (when compared with the value of biofuels) while generating an interesting low-cost by-product, which is generally rich in cellulose and other seaweed polysaccharides, poor in lignin and that does not compete with human food uses. Besides the sustainability, economic and environmental reasons for a seaweed's cascade biorefinery approach, there are also processing advantages over the direct use of seaweeds for biofuels: industrial enzymes for hydrolyzing seaweeds' hydrocolloids are hardly available and those available have prohibitive prices; therefore, using wastes provide a residue which is highly concentrated in cellulose (which has a commercial viability and sustainability in saccharification procedures) is an advantage; furthermore, a significant amount of salts, which may be detrimental for the fermentation processes, are removed and lower amounts of inhibitors (e.g. HMF or acids) are expected (when compared to the whole seaweed).

Besides the residues from the phycocolloids industry, other biorefinery approaches may be considered. For instance, four different exploitable fractions were sequentially obtained from Ulva fasciata, including one rich in minerals, one rich in lipids, one rich in ulvan and, finally, the fraction rich in cellulose (Trivedi et al., 2016). Even within the phycocolloids industry, other exploitable fractions, such as pigments, proteins or lipids may also be considered (Jung et al., 2013; Mensi, 2019).

In this sense, some authors have applied the pretreatment or combined pretreatments for the integral valorization of whole seaweed. Baghel and co-workers (2015) proposed an integrated process (comprised of sequential stages of extraction) to obtain several commodities from red algal biomass (Gracilaria dura and Gelidiella acerosa). Firstly, phycobilin pigments and protein were extracted using $0.1 \mathrm{M}$ phosphate buffer during $12 \mathrm{~h}$ at $4{ }^{\circ} \mathrm{C}$. The free-pigments residue was subjected to chloroform-methanol solvent mixture $\left(2000 \mathrm{~g} 4{ }^{\circ} \mathrm{C}\right.$ for $\left.20 \mathrm{~min}\right)$ for lipids extraction. Afterward, the remained residue was treated by 
hydrothermal treatment $\left(120{ }^{\circ} \mathrm{C}\right.$ for $\left.1.5 \mathrm{~h}\right)$ to extract agar in the liquid phase. Finally, solid residue after bleaching $\left(60{ }^{\circ} \mathrm{C}\right.$ for $\left.8 \mathrm{~h}\right)$ was processed by alkali treatment $\left(0.5 \mathrm{M} \mathrm{NaOH}\right.$ at $60{ }^{\circ} \mathrm{C}$ for $\left.12 \mathrm{~h}\right)$ to obtain cellulose that was subsequently hydrolyzed by cellulases enzymes to obtain glucose and fermented to ethanol by the yeast $S$. cerevisiae. Other integrated valorization alternative consisted on a simple and environmentally friendly process of autohydrolysis (at milder conditions $150{ }^{\circ} \mathrm{C}$ ) for the fractionation of invasive algae (Sargassum) to produce oligosaccharides in the liquid phase and the simultaneous saccharification and fermentation of the solid residue after treatment to produce ethanol (del Río et al., 2019). Under these conditions, $15.22 \mathrm{~g} / \mathrm{L}$ of oligomers (composed mainly by fucooligosaccharides), $90 \%$ of cellulose recovery and $11.32 \mathrm{~g} / \mathrm{L}$ of ethanol were achieved.

\section{Future perspective}

The high carbohydrate content in macroalgae makes it a very attractive substrate for biofuels production. Considering the huge potential of this biomass, a pretreatment that allows suitable fractionation of whole seaweed should be proposed, not only for biofuels production but also to be used as food ingredient, additive, cosmetic, fertilizer and medicine, contributing to the economic feasibility of this biorefinery. In this sense, innovative and environmentally sustainable processes are necessary to fractionate the seaweed biomass. As shown from data discussed in this review, the most efficient and cost-effective treatment to obtain fermentable sugars is dilute acid pretreatment. Nevertheless, the need for more environmentally friendly processes promotes the research on pretreatments using green solvents (such as water, deep eutectic solvents, etc.) that combined with efficient heating systems might also contribute to the viability of these integrated seaweed biorefineries. Moreover, there is a need for inexpensive and environmentally friendly solutions for the saccharification of non-cellulosic polysaccharides. The availability of enzyme cocktails for selective hydrolysis of seaweed polysaccharides is one of the most significant bottlenecks. In this sense, the use of residues from phycocolloids industries is presented as suitable alternative since cellulolytic enzymes used for lignocellulosic biomass saccharification can be applied. On the other hand, the isolation and characterization of novel enzymes from marine microorganisms is a recent trend that can lead to the discovery of effective enzymes for the saccharification of non-cellulosic seaweed polysaccharides. Thus, it is expected that the advances in biotechnology allow the development of microorganisms able to hydrolysate and ferment these sugars in a consolidated bioprocessing, employing genetic transformations and metabolic engineering tools. The suitable fractionation pretreatment and consolidated bioprocessing could drive the development of seaweed biomass-to-biofuels processes.

\section{Conclusions}

Seaweed is a readily available and interesting resource for biofuel production and its appropriate fractionation is the main challenge for the development of a marine biorefinery. For that, a rational processing of whole seaweed based on (a) suitable pretreatment(s) that allows the recovery and valorization of the main fractions in separated streams is imperative. Therefore, research on cutting-edge environmentally friendly technologies are required. In particular, aqueous treatments stand up considering seaweed innate high-water content. Currently developing alternatives (such as enzymatic treatment and the use of deep eutectic solvents) could also play an important role in coming years.

\section{Declaration of Competing Interest}

The authors declare that they have no known competing financial interests or personal relationships that could have appeared to influence the work reported in this paper.

\section{Acknowledgments}

Authors are grateful to Spanish Ministry of Economy and Competitiveness (research project "Multistage processes for the integral benefit of macroalgae and vegetable biomass" with reference CTM2015-68503) and to the CITACA Strategic Partnership ED431E 2018/07 (Xunta de Galicia, Spain), these programs partially funded by FEDER of European Union. Pablo G. del Río is grateful to the Ministry of Science, Innovation and Universities of Spain for his FPU research grant (FPU16/04077). This study was supported by the Portuguese Foundation for Science and Technology (FCT, Portugal) under the scope of the strategic funding of UID/BIO/04469/2019 unit, the BioTecNorte operation (NORTE-01-0145-FEDER-000004) funded by European Regional Development Fund under the scope of Norte2020—Programa Operacional Regional do Norte, the MultiBiorefinery project (POCI01-0145-FEDER-016403), the AlgaePlas (FCT, project PTDC/BII-BIO/ 29242/2017) and the Biomass and Bioenergy Research Infrastructure (PINFRA/22059/2016).

\section{References}

Al Abdallah, Q., Nixon, B.T., Fortwendel, J.R., 2016. The enzymatic conversion of major algal and cyanobacterial carbohydrates to bioethanol. Front. Energy Res. 4, 1-15.

Alalwan, H.A., Alminshid, A.H., Aljaafari, H.A.S., 2019. Promising evolution of biofuel generations. Subject review. Renew. Energy Focus 28, 127-139.

Alexander, K.A., Hughes, A.D., 2017. A problem shared: Technology transfer and development in European integrated multi-trophic aquaculture (IMTA). Aquaculture 473, 13-19.

Alvira, P., Tomás-Pejó, E., Ballesteros, M., Negro, M.J., 2010. Pretreatment technologies for an efficient bioethanol production process based on enzymatic hydrolysis: a review. Bioresour. Technol. 101, 4851-4861.

Amamou, S., Sambusiti, C., Monlau, F., Dubreucq, E., Barakat, A., 2018. Mechano-enzymatic deconstruction with a new enzymatic cocktail to enhance enzymatic hydrolysis and bioethanol fermentation of two macroalgae species. Molecules 23, 174.

Amoah, J., Kahar, P., Ogino, C., Kondo, A., 2019. Bioenergy and biorefinery: feedstock, biotechnological conversion, and products. Biotechnol. J. 14, 1800494.

Appiah-Nkansah, N.B., Li, J., Rooney, W., Wang, D., 2019. A review of sweet sorghum as a viable renewable bioenergy crop and its techno-economic analysis. Renew. Energy $143,1121-1132$.

Baghel, R.S., Trivedi, N., Gupta, V., Neori, A., Reddy, C.R.K., Lali, A., Jha, B., 2015. Biorefining of marine macroalgal biomass for production of biofuel and commodity chemicals. Green Chem. 17, 2436-2443.

Balat, M., Balat, H., Öz, C., 2008. Progress in bioethanol processing. Prog. Energy Combust. Sci. 34, 551-573.

Balboa, E.M., Gallego-Fábrega, C., Moure, A., Domínguez, H., 2016. Study of the seasonal variation on proximate composition of oven-dried Sargassum muticum biomass collected in Vigo Ria, Spain. J. Appl. Phycol. 28, 1943-1953.

Balboa, E.M., Rivas, S., Moure, A., Domínguez, H., Parajó, J.C., 2013. Simultaneous extraction and depolymerization of fucoidan from sargassum muticum in aqueous media. Mar. Drugs 11, 4612-4627.

Barbot, Y.N., Al-Ghaili, H., Benz, R., 2016. A review on the valorization of macroalgal wastes for biomethane production. Mar. Drugs 14.

Ben Yahmed, N., Berrejeb, N., Jmel, M.A., Jazzar, S., Marzouki, M.N., Smaali, I., 2018. Efficient biocatalytic conversion of stranded green macroalgal biomass using a specific cellulases-based cocktail. Waste Biomass Valoriz. 1-12.

Ben Yahmed, N., Jmel, M.A., Ben Alaya, M., Bouallagui, H., Marzouki, M.N., Smaali, I., 2016. A biorefinery concept using the green macroalgae Chaetomorpha linum for the coproduction of bioethanol and biogas. Energy Convers. Manag. 119, 257-265.

Bharathiraja, B., Chakravarthy, M., Ranjith Kumar, R., Yogendran, D., Yuvaraj, D., Jayamuthunagai, J., Praveen Kumar, R., Palani, S., 2015. Aquatic biomass (algae) as a future feed stock for bio-refineries: a review on cultivation, processing and products. Renew. Sustain. Energy Rev. 47, 634-653.

Borines, M.G., de Leon, R.L., Cuello, J.L., 2013. Bioethanol production from the macroalgae Sargassum spp. Bioresour. Technol. 138, 22-29.

Cardoso, S., Carvalho, L., Silva, P., Rodrigues, M., Pereira, O., Pereira, L., 2014. Bioproducts from Seaweeds: a Review with Special Focus on the Iberian Peninsula. Curr. Org. Chem. 18, 896-917.

Carr, A.G., Mammucari, R., Foster, N.R., 2011. A review of subcritical water as a solvent and its utilisation for the processing of hydrophobic organic compounds. Chem. Eng. J. 172, 1-17.

Cernadas, H., Flórez-Fernández, N., González-Muñoz, M.J., Torres, M.D., 2019. Retrieving of high-value biomolecules from edible Himanthalia elongata brown seaweed using hydrothermal processing 7, 275-286.

Chauhan, P.S., Saxena, A., 2016. Bacterial carrageenases: an overview of production and biotechnological applications. 3 Biotech 6 .

Chen, H., Zhou, D., Luo, G., Zhang, S., Chen, J., 2015. Macroalgae for biofuels production: Progress and perspectives. Renew. Sustain. Energy Rev. 47, 427-437.

Chew, K.W., Juan, J.C., Phang, S.M., Ling, T.C., Show, P.L., 2018a. An overview on the development of conventional and alternative extractive methods for the purification 
of agarose from seaweed. Sep. Sci. Technol. 53, 467-480.

Chew, K.W., Show, P.L., Yap, Y.J., Juan, J.C., Phang, S.M., 2018b. Sonication and grinding pre-treatments on Gelidium amansii seaweed for the extraction and characterization of Agarose 12, 1-7.

Cho, H., Ra, C.H., Kim, S.K., 2014. Ethanol production from the seaweed Gelidium amansii, using specific sugar acclimated yeasts. J. Microbiol. Biotechnol. 24, 264-269.

Chow, M.C., Jackson, W.R., Chaffee, A.L., Marshall, M., 2013. Thermal treatment of algae for production of biofuel. Energy and Fuels 27, 1926-1950.

Clarke, C.J., Tu, W., Levers, O., Bro, A., Hallett, J.P., 2018. Green and sustainable solvents in chemical processes. Chem. Rev. 118, 747-800.

Costa, C.E., Romaní, A., Cunha, J.T., Johansson, B., Domingues, L., 2017. Integrated approach for selecting efficient Saccharomyces cerevisiae for industrial lignocellulosic fermentations: Importance of yeast chassis linked to process conditions. Bioresour. Technol. 227, 24-34.

Crampon, C., Boutin, O., Badens, E., 2011. Supercritical carbon dioxide extraction of molecules of interest from microalgae and seaweeds. Ind. Eng. Chem. Res. 50, 8941-8953.

Das, A.K., Sharma, M., Mondal, D., Prasad, K., 2016. Deep eutectic solvents as efficient solvent system for the extraction of $\kappa$-carrageenan from Kappaphycus alvarezii. Carbohydr. Polym. 136, 930-935.

Dave, N., Selvaraj, R., Varadavenkatesan, T., Vinayagam, R., 2019. A critical review on production of bioethanol from macroalgal biomass. Algal Res. 42101606.

De Ramon N’Yeurt, A., Iese, V., 2015. The proliferating brown alga Sargassum polycystum in Tuvalu, South Pacific: assessment of the bloom and applications to local agriculture and sustainable energy. J. Appl. Phycol. 27, 2037-2045.

del Río, P.G., Domínguez, E., Domínguez, V.D., Romaní, A., Domingues, L., Garrote, G., 2019. Third generation bioethanol from invasive macroalgae Sargassum muticum using autohydrolysis pretreatment as first step of a biorefinery. Renew. Energy 141, 728-735.

El Harchi, M., Fakihi Kachkach, F.Z., El Mtili, N., 2018. Optimization of thermal acid hydrolysis for bioethanol production from Ulva rigida with yeast Pachysolen tannophilus. South African J. Bot. 115, 161-169.

Enquist-Newman, M., Faust, A.M.E., Bravo, D.D., Santos, C.N.S., Raisner, R.M., Hanel, A., Sarvabhowman, P., Le, C., Regitsky, D.D., Cooper, S.R., Peereboom, L., Clark, A., Martinez, Y., Goldsmith, J., Cho, M.Y., Donohoue, P.D., Luo, L., Lamberson, B., Tamrakar, P., Kim, E.J., Villari, J.L., Gill, A., Tripathi, S.A., Karamchedu, P., Paredes, C.J., Rajgarhia, V., Kotlar, H.K., Bailey, R.B., Miller, D.J., Ohler, N.L., Swimmer, C., Yoshikuni, Y., 2014. Efficient ethanol production from brown macroalgae sugars by a synthetic yeast platform. Nature 505, 239-243.

Ferdouse, F., Holdt, S.L., Smith, R., Murúa, P., Yang, Z., 2018. The global status of seaweed production, trade and utilization. FAO Globefish Res. Program. 124, 120.

Flórez-Fernández, N., Torres, M.D., González-Muñoz, M.J., Domínguez, H., 2019. Recovery of bioactive and gelling extracts from edible brown seaweed Laminaria ochroleuca by non-isothermal autohydrolysis. Food Chem. 277, 353-361.

Ganesh Saratale, R., Kumar, G., Banu, R., Xia, A., Periyasamy, S., Dattatraya Saratale, G., 2018. A critical review on anaerobic digestion of microalgae and macroalgae and codigestion of biomass for enhanced methane generation. Bioresour. Technol. 262, 319-332.

Ge, L., Wang, P., Mou, H., 2011. Study on saccharification techniques of seaweed wastes for the transformation of ethanol. Renew. Energy 36, 84-89.

Gereniu, C.R.N., Saravana, P.S., Chun, B.S., 2018. Recovery of carrageenan from Solomon Islands red seaweed using ionic liquid-assisted subcritical water extraction. Sep. Purif. Technol. 196, 309-317.

Ghadiryanfar, M., Rosentrater, K.A., Keyhani, A., Omid, M., 2016. A review of macroalgae production, with potential applications in biofuels and bioenergy. Renew. Sustain. Energy Rev. 54, 473-481.

Gomez, C.G., Pérez Lambrecht, M.V., Lozano, J.E., Rinaudo, M., Villar, M.A., 2009. Influence of the extraction-purification conditions on final properties of alginates obtained from brown algae (Macrocystis pyrifera). Int. J. Biol. Macromol. 44, 365-371.

Hassan, S.S., Williams, G.A., Jaiswal, A.K., 2018. Emerging technologies for the pretreatment of lignocellulosic biomass. Bioresour. Technol. 262, 310-318.

Hong, Y., Chen, W., Luo, X., Pang, C., Lester, E., Wu, T., 2017. Microwave-enhanced pyrolysis of macroalgae and microalgae for syngas production. Bioresour. Technol. 237, 47-56.

Hou, X., From, N., Angelidaki, I., Huijgen, W.J.J., Bjerre, A.B., 2017. Butanol fermentation of the brown seaweed Laminaria digitata by Clostridium beijerinckii DSM-6422. Bioresour. Technol. 238, 16-21.

Hu, Z., Foston, M., Ragauskas, A.J., 2011. Comparative studies on hydrothermal pretreatment and enzymatic saccharification of leaves and internodes of alamo switchgrass. Bioresour. Technol. 102, 7224-7228.

Huang, R., Cao, M., Guo, H., Qi, W., Su, R., He, Z., 2014. Enhanced ethanol production from pomelo peel waste by integrated hydrothermal treatment, multienzyme formulation, and fed-batch operation. J. Agric. Food Chem. 62, 4643-4651.

Huesemann, M.H., Kuo, L.J., Urquhart, L., Gill, G.A., Roesijadi, G., 2012. Acetone-butanol fermentation of marine macroalgae. Bioresour. Technol. 108, 305-309.

Jeong, T.S., Kim, Y.S., Oh, K.K., 2011. Two-stage acid saccharification of fractionated Gelidium amansii minimizing the sugar decomposition. Bioresour. Technol. 102, 10529-10534.

Ji, S.Q., Wang, B., Lu, M., Li, F.L., 2016. Direct bioconversion of brown algae into ethanol by thermophilic bacterium Defluviitalea phaphyphila. Biotechnol. Biofuels 9, 1-10.

Jiang, R., Ingle, K.N., Golberg, A., 2016. Macroalgae (seaweed) for liquid transportation biofuel production: what is next? Algal Res. 14, 48-57.

Jin, B., Duan, P., Xu, Y., Wang, F., Fan, Y., 2013. Co-liquefaction of micro- and macroalgae in subcritical water. Bioresour. Technol. 149, 103-110.
John, R.P., Anisha, G.S., Nampoothiri, K.M., Pandey, A., 2011. Micro and macroalgal biomass: arenewable source for bioethanol. Bioresour. Technol. 102, 186-193.

Jung, K.A., Lim, S.R., Kim, Y., Park, J.M., 2013. Potentials of macroalgae as feedstocks for biorefinery. Bioresour. Technol. 135, 182-190.

Kadam, S.U., Tiwari, B.K., Smyth, T.J., Donnell, C.P.O., 2015. Optimization of ultrasound assisted extraction of bioactive components from brown seaweed Ascophyllum nodosum using response surface methodology. Ultrason. - Sonochemistry 23, 308-316.

Kang, D.H., Hyeon, J.E., You, S.K., Kim, S.W., Han, S.O., 2014. Efficient enzymatic degradation process for hydrolysis activity of the Carrageenan from red algae in marine biomass. J. Biotechnol. 192, 108-113.

Karray, R., Hamza, M., Sayadi, S., 2015. Evaluation of ultrasonic, acid, thermo-alkaline and enzymatic pre-treatment on anaerobic digestion of Ulva rigida for biogas production. Bioresour. Technol. 187, 205-213.

Kerton, F.M., Liu, Y., Omari, K.W., Hawboldt, K., 2013. Green chemistry and the oceanbased biorefinery. Green Chem. 15, 860-871.

Khoo, C.G., Dasan, Y.K., Lam, M.K., Lee, K.T., 2019. Algae biorefinery: Review on a broad spectrum of downstream processes and products. Bioresour. Technol. 292121964.

Kidgell, J.T., Magnusson, M., Nys, R. De, Glasson, C.R.K., 2019. Ulvan: a systematic review of extraction, composition and function. Algal Res. 39101422.

Kim, Dong Hyun, Kim, Do Hyoung, Lee, S.H., Kim, K.H., 2018. A novel ß-glucosidase from Saccharophagus degradans 2-40T for the efficient hydrolysis of laminarin from brown macroalgae. Biotechnol. Biofuels 11, 1-10.

Kim, H.M., Wi, S.G., Jung, S., Song, Y., Bae, H.J., 2015. Efficient approach for bioethanol production from red seaweed Gelidium amansii. Bioresour. Technol. 175, 128-134.

Kim, H.T., Lee, S., Kim, K.H., Choi, I.G., 2012. The complete enzymatic saccharification of agarose and its application to simultaneous saccharification and fermentation of agarose for ethanol production. Bioresour. Technol. 107, 301-306.

Kim, J.K., Yarish, C., Hwang, E.K., Park, M., Kim, Y., 2017. Seaweed aquaculture: cultivation technologies, challenges and its ecosystem services. Algae 32, 1-13.

Korzen, L., Pulidindi, I.N., Israel, A., Abelson, A., Gedanken, A., 2015. Single step production of bioethanol from the seaweed Ulva rigida using sonication. RSC Adv. 5, 16223-16229.

Kostas, E.T., White, D.A., Du, C., Cook, D.J., 2016. Selection of yeast strains for bioethanol production from UK seaweeds. J. Appl. Phycol. 28, 1427-1441.

Kumar, S., Gupta, R., Kumar, G., Sahoo, D., Chander, R., 2013. Bioethanol production from Gracilaria verrucosa, a red alga, in a biorefinery approach. Bioresour. Technol. 135, 150-156.

Lee, J.Y., Kim, Y.S., Um, B.H., Oh, K.K., 2013. Pretreatment of Laminaria japonica for bioethanol production with extremely low acid concentration. Renew. Energy 54, 196-200.

Li, H., Qu, Y., Yang, Y., Chang, S., Xu, J., 2016. Microwave irradiation - A green and efficient way to pretreat biomass. Bioresour. Technol. 199, 34-41.

Li, K., Liu, S., Liu, X., 2014. An overview of algae bioethanol production. Int. J. energy Res. 38, 965-977.

Malihan, L.B., Nisola, G.M., Mittal, N., Seo, J.G., Chung, W.J., 2014. Blended ionic liquid systems for macroalgae pretreatment. Renew. Energy 66, 596-604.

Maneein, S., Milledge, J.J., Nielsen, B. V., Harvey, P.J., 2018. A review of seaweed pretreatment methods for enhanced biofuel production by anaerobic digestion or fermentation. Fermentation 4.

Manns, D., Deutschle, A.L., Saake, B., Meyer, A.S., 2014. Methodology for quantitative determination of the carbohydrate composition of brown seaweeds (Laminariaceae) RSC Adv. 4, 25736-25746.

Marinho, G.S., Holdt, S.L., Jacobsen, C., Angelidaki, I., 2015. Lipids and composition of fatty acids of saccharina latissima cultivated year-round in integrated multi-trophic aquaculture. Mar. Drugs 4357-4374.

Meillisa, A., Woo, H., Chun, B., 2015. Production of monosaccharides and bio-active compounds derived from marine polysaccharides using subcritical water hydrolysis. Food Chem. 171, 70-77.

Meinita, M.D.N., Marhaeni, B., Hong, Y.K., Jeong, G.T., 2017. Enzymatic saccharification of agar waste from Gracilaria verrucosa and Gelidium latifolium for bioethanol production. J. Appl. Phycol. 29, 3201-3209.

Mensi, F., 2019. Agar yield from R-phycoerythrin extraction by-product of the red alga Gracilaria verrucosa. J. Appl. Phycol. 31, 741-751.

Mhatre, A., Navale, M., Trivedi, N., Pandit, R., Lali, A.M., 2018. Pilot scale flat panel photobioreactor system for mass production of Ulva lactuca (Chlorophyta). Bioresour. Technol. 249, 582-591.

Michalak, I., 2018. Experimental processing of seaweeds for biofuels. Wiley Interdiscip. Rev. Energy Environ. 7 e228.

Milledge, J.J., Nielsen, B.V., Bailey, D., 2016. High-value products from macroalgae: the potential uses of the invasive brown seaweed, Sargassum muticum. Rev. Environ. Sci. Biotechnol. 15, 67-88.

Mittal, R., Tavanandi, H.A., Mantri, V.A., Raghavarao, K.S.M.S., 2017. Ultrasound assisted methods for enhanced extraction of phycobiliproteins from marine macroalgae, Gelidium pusillum (Rhodophyta). Ultrason. - Sonochemistry 38, 92-103.

Møller, M., Manns, D., Este, M.D., Krause-jensen, D., Bo, M., Mørk, M., Alvarado-morales, M., Angelidaki, I., Bruhn, A., 2016. Variation in biochemical composition of Saccharina latissima and Laminaria digitata along an estuarine salinity gradient in inner Danish waters. Algal 13, 235-245.

Montingelli, M.E., Benyounis, K., Stokes, J., Olabi, A.G., 2016. Pretreatment of macroalgal biomass for biogas production. Energy Convers. Manag. 108, 202-209.

Mustafa, A., Turner, C., 2011. Pressurized liquid extraction as a green approach in food and herbal plants extraction: A review. Anal. Chim. Acta 703, 8-18.

Navya, P., Khora, S.S., 2017. Ultrasonic-enhanced and hot water extraction of antioxidant sulfated polysaccharides from Codium tomentosum stackhouse, 1797. Biomed. Res. $28,8616-8623$.

Nguyen, T.H., Ra, C.H., Sunwoo, I.Y., Jeong, G.T., Kim, S.K., 2017. Bioethanol production 
from Gracilaria verrucosa using Saccharomyces cerevisiae adapted to $\mathrm{NaCl}$ or galactose. Bioprocess Biosyst. Eng. 40, 529-536.

Offei, F., Mensah, M., Thygesen, A., Kemausuor, F., 2018. Seaweed bioethanol production: aprocess selection review on hydrolysis and fermentation. Fermentation 4, $1-18$.

Ong, H.C., Chen, W.H., Farooq, A., Gan, Y.Y., Lee, K.T., Ashokkumar, V., 2019. Catalytic thermochemical conversion of biomass for biofuel production: a comprehensive review. Renew. Sustain. Energy Rev. 113109266.

Park, J., Yoon, J., Park, H., Jin, Y., Jung, D., Kim, S., 2011. Feasibility of biohydrogen production from Gelidium amansii. Int. J. Hydrogen Energy 36, 13997-14003.

Parsa, M., Nourani, M., Baghdadi, M., Hosseinzadeh, M., Pejman, M., 2019. Biochars derived from marine macroalgae as a mesoporous by-product of hydrothermal liquefaction process: characterization and application in wastewater treatment. J. Water Process Eng. 32100942.

Peña-Rodríguez, A., Mawhinney, T.P., Ricque-Marie, D., Cruz-Suárez, L.E., 2011a. Chemical composition of cultivated seaweed Ulva clathrata (Roth) C. Agardh. Food Chem. 129, 491-498.

Peña-Rodríguez, A., Mawhinney, T.P., Ricque-Marie, D., Cruz-Suárez, L.E., 2011b. Chemical composition of cultivated seaweed Ulva clathrata (Roth) C. Agardh. Food Chem. 129, 491-498.

Pereira, F.B., Guimarães, P.M.R., Gomes, D.G., Mira, N.P., Teixeira, M.C., Sá-Correia, I., Domingues, L., 2011. Identification of candidate genes for yeast engineering to improve bioethanol production in very high gravity and lignocellulosic biomass industrial fermentations. Biotechnol. Biofuels 4, 1-12.

Pérez-Larrán, P., Torres, M.D., Flórez-Fernández, N., Balboa, E.M., Moure, A., Domínguez, H., 2019. Green technologies for cascade extraction of Sargassum muticum bioactives. J. Appl. Phycol. 31, 2481-2495.

Pérez-López, P., Balboa, E.M., González-García, S., Domínguez, H., Feijoo, G., Moreira, M.T., 2014. Comparative environmental assessment of valorization strategies of the invasive macroalgae Sargassum muticum. Bioresour. Technol. 161, 137-148.

Pezoa-Conte, R., Leyton, A., Anugwom, I., von Schoultz, S., Paranko, J., Mäki-Arvela, P., Willför, S., Muszyński, M., Nowicki, J., Lienqueo, M.E., Mikkola, J.P., 2015. Deconstruction of the green alga Ulva rigida in ionic liquids: closing the mass balance. Algal Res. 12, 262-273.

Plaza, M., Amigo-Benavent, M., del Castillo, M.D., Ibáñez, E., Herrero, M., 2010a. Facts about the formation of new antioxidants in natural samples after subcritical water extraction. Food Res. Int. 43, 2341-2348.

Plaza, M., Santoyo, S., Jaime, L., García-Blairsy Reina, G., Ibáñez, E., 2010b. Screening for bioactive compounds from algae. J. Pharm Biomed Anal. 51, 450-455.

Porse, H., Rudolph, B., 2017. The seaweed hydrocolloid industry: 2016 updates, requirements, and outlook. J. Appl. Phycol. 29, 2187-2200.

Postma, P.R., Akkerman, R.J., Olivieri, G., 2018. Biorefinery of the macroalgae Ulva lactuca: extraction of proteins and carbohydrates by mild disintegration. J. Appl. Phycol. 30, 1281-1293.

Prabhu, M.S., Levkov, K., Livney, Y.D., Israel, A., Golberg, A., 2019. High-voltage pulsed electric field preprocessing enhances extraction of starch, proteins, and ash from marine macroalgae ulva ohnoi. ACS Sustain. Chem. Eng. 7, 17453-17463.

Praveen, M.A., Parvathy, K.R.K., Balasubramanian, P., Jayabalan, R., 2019. An overview of extraction and purification techniques of seaweed dietary fibers for immunomodulation on gut microbiota. Trends Food Sci. Technol. 92, 46-64.

Rey, F., Lopes, D., Maciel, E., Monteiro, J., Skjermo, J., Funderud, J., Raposo, D., Domingues, P., Calado, R., Domingues, M.R., 2019. Polar lipid profile of Saccharina latissima, a functional food from the sea. Algal Res. 39101473.

Rigdon, A.R., Jumpponen, A., Vadlani, P.V., Maier, D.E., 2013. Impact of various storage conditions on enzymatic activity, biomass components and conversion to ethanol yields from sorghum biomass used as a bioenergy crop. Bioresour. Technol. 132, 269-275.

Robak, K., Balcerek, M., 2018. Review of second generation bioethanol production from residual biomass. Food Technol. Biotechnol. 56, 174-187.

Robin, A., Chavel, P., Chemodanov, A., Israel, A., Golberg, A., 2017. Diversity of monosaccharides in marine macroalgae from the Eastern Mediterranean Sea. Algal Res. 28, 118-127.

Rocha, C.M.R., Genisheva, Z., Ferreira-Santos, P., Rodrigues, R., Vicente, A.A., Teixeira, J.A., Pereira, R.N., 2018. Electric field-based technologies for valorization of bioresources. Bioresour. Technol. 254, 325-339.

Rocha, C.M.R., Sousa, A.M.M., Kim, J.K., Magalhães, J.M.C.S., Yarish, C., Gonçalves, M., do, P., 2019. Characterization of agar from Gracilaria tikvahiae cultivated for nutrient bioextraction in open water farms. Food Hydrocoll. 89, 260-271.

Rodríguez-Jasso, R.M., Mussatto, S.I., Pastrana, L., Aguilar, C.N., Teixeira, J.A., 2013. Extraction of sulfated polysaccharides by autohydrolysis of brown seaweed Fucus vesiculosus. J. Appl. Phycol. 25, 31-39.

Romaní, A., Pereira, F., Johansson, B., Domingues, L., 2015. Metabolic engineering of Saccharomyces cerevisiae ethanol strains PE-2 and CAT-1 for efficient lignocellulosic fermentation. Bioresour. Technol. 179, 150-158.

Ruiz, H.A., Rodríguez-Jasso, R.M., Fernandes, B.D., Vicente, A.A., Teixeira, J.A., 2013. Hydrothermal processing, as an alternative for upgrading agriculture residues and marine biomass according to the biorefinery concept: a review. Renew. Sustain. Energy Rev. 21, 35-51.

Sadhukhan, J., Gadkari, S., Martinez-Hernandez, E., Ng, K.S., Shemfe, M., Torres-Garcia, E., Lynch, J., 2019. Novel macroalgae (seaweed) biorefinery systems for integrated chemical, protein, salt, nutrient and mineral extractions and environmental protection by green synthesis and life cycle sustainability assessments. Green Chem. 21, 2635-2655.

Saravana, P.S., Cho, Y.N., Woo, H.C., Chun, B.S., 2018. Green and efficient extraction of polysaccharides from brown seaweed by adding deep eutectic solvent in subcritical water hydrolysis. J. Clean. Prod. 198, 1474-1484.
Schultz-Jensen, N., Thygesen, A., Leipold, F., Thomsen, S.T., Roslander, C., Lilholt, H., Bjerre, A.B., 2013. Pretreatment of the macroalgae Chaetomorpha linum for the production of bioethanol - Comparison of five pretreatment technologies. Bioresour. Technol. 140, 36-42.

Sharma, S., Neves, L., Funderud, J., Torunn, L., Øverland, M., 2018. Seasonal and depth variations in the chemical composition of cultivated Saccharina latissima. Algal Res. 32, 107-112.

Shukla, R., Kumar, M., Chakraborty, S., Gupta, R., Kumar, S., Sahoo, D., Kuhad, R.C., 2016. Process development for the production of bioethanol from waste algal biomass of Gracilaria verrucosa. Bioresour. Technol. 220, 584-589.

Sirajunnisa, A.R., Surendhiran, D., 2016. Algae - A quintessential and positive resource of bioethanol production: A comprehensive review. Renew. Sustain. Energy Rev. 66, $248-267$.

Soliman, R.M., Younis, S.A., El-Gendy, N.S., Mostafa, S.S.M., El-Temtamy, S.A., Hashim, A.I., 2018. Batch bioethanol production via the biological and chemical saccharification of some Egyptian marine macroalgae. J. Appl. Microbiol. 125, 422-440.

Sousa, A.M.M., Alves, V.D., Morais, S., Delerue-matos, C., Gonçalves, M.P., 2010. Agar extraction from integrated multitrophic aquacultured Gracilaria vermiculophylla : Evaluation of a microwave-assisted process using response surface methodology. Bioresour. Technol. 101, 3258-3267.

Sudhakar, K., Mamat, R., Samykano, M., Azmi, W.H., Ishak, W.F.W., Yusaf, T., 2018. An overview of marine macroalgae as bioresource. Renew. Sustain. Energy Rev. 91, $165-179$.

Sukwong, P., Ra, C.H., Sunwoo, I.Y., Tantratian, S., Jeong, G.T., Kim, S.K., 2018. Improved fermentation performance to produce bioethanol from Gelidium amansii using Pichia stipitis adapted to galactose. Bioprocess Biosyst. Eng. 41, 953-960.

Sun, Shaoni, Sun, Shaolong, Cao, X., Sun, R., 2016. The role of pretreatment in improving the enzymatic hydrolysis of lignocellulosic materials. Bioresour. Technol. 199, 49-58.

Tabarsa, M., Rezaei, M., Ramezanpour, Z., Waaland, J.R., 2012. Chemical compositions of the marine algae Gracilaria salicornia (Rhodophyta) and Ulva lactuca (Chlorophyta) as a potential food source. J. Sci. Food Agric. 92, 2500-2506.

Tan, I.S., Lee, K.T., 2015. Solid acid catalysts pretreatment and enzymatic hydrolysis of macroalgae cellulosic residue for the production of bioethanol. Carbohydr. Polym. 124, 311-321.

Tan, I.S., Lee, K.T., 2014. Enzymatic hydrolysis and fermentation of seaweed solid wastes for bioethanol production: an optimization study. Energy 78, 53-62.

Tapia-Tussell, R., Avila-Arias, J., Maldonado, J.D., Valero, D., Olguin-Maciel, E., PérezBrito, D., Alzate-Gaviria, L., 2018. Biological pretreatment of mexican caribbean macroalgae consortiums using Bm-2 strain (Trametes hirsuta) and its enzymatic broth to improve biomethane potential. Energies 11.

Thompson, T.M., Young, B.R., Baroutian, S., 2019. Advances in the pretreatment of brown macroalgae for biogas production. Fuel Process. Technol. 195106151.

Tierney, M.S., Smyth, T.J., Hayes, M., Soler-vila, A., Croft, A.K., Brunton, N., 2013. Influence of pressurised liquid extraction and solid - liquid extraction methods on the phenolic content and antioxidant activities of Irish macroalgae. Int. J. Food Sci. Technol. 48, 860-869.

Torres, M.D., Kraan, S., Domínguez, H., 2019. Seaweed biorefinery. Rev. Environ. Sci. Biotechnol.

Trivedi, N., Baghel, R.S., Bothwell, J., Gupta, V., Reddy, C.R.K., Lali, A.M., Jha, B., 2016. An integrated process for the extraction of fuel and chemicals from marine macroalgal biomass. Sci. Rep. 6, 1-8.

Trivedi, T.J., Kumar, A., 2014. Efficient Extraction of Agarose from Red Algae Using Ionic Liquids. Green Sustain. Chem. 04, 190-201.

Tu, W.-C., Hallett, J.P., 2019. Recent advances in the pretreatment of lignocellulosic biomass. Curr. Opin. Green Sustain. Chem. 20, 11-17.

Uju, Wijayanta, Goto, A.T., Kamiya, M., 2015. Great potency of seaweed waste biomass from the carrageenan industry for bioethanol production by peracetic acid-ionic liquid pretreatment. Biomass Bioener. 81, 63-69.

van der Wal, H., Sperber, B.L.H.M., Houweling-Tan, B., Bakker, R.R.C., Brandenburg, W., López-Contreras, A.M., 2013. Production of acetone, butanol, and ethanol from biomass of the green seaweed Ulva lactuca. Bioresour. Technol. 128, 431-437.

Van Hal, J.W., Huijgen, W.J.J., López-Contreras, A.M., 2014. Opportunities and challenges for seaweed in the biobased economy. Trends Biotechnol. 32, 231-233.

Vanegas, C., Hernon, A., Bartlett, J., Vanegas, C., Hernon, A., Bartlett, J., 2014. Influence of Chemical , Mechanical , and Thermal Pretreatment on the Release of Macromolecules from Two Irish Seaweed Species Influence of Chemical , Mechanical , and Thermal Pretreatment on the Release of Macromolecules from Two Irish Seaweed Species 6395.

Vieira, F.A., Guilherme, R.J.R., Neves, M.C., Rego, A., Abreu, M.H., Coutinho, J.A.P., Ventura, S.P.M., 2018. Recovery of carotenoids from brown seaweeds using aqueous solutions of surface-active ionic liquids and anionic surfactants. Sep. Purif. Technol. 196, 300-308.

Viola, E., Cardinale, M., Santarcangelo, R., Villone, A., Zimbardi, F., 2008. Ethanol from eel grass via steam explosion and enzymatic hydrolysis. Biomass Bioenergy 32, 613-618.

Vo Dinh, T., Saravana, P.S., Woo, H.C., Chun, B.S., 2018. Ionic liquid-assisted subcritical water enhances the extraction of phenolics from brown seaweed and its antioxidant activity. Sep. Purif. Technol. 196, 287-299.

Wang, J., Wang, H., Mou, H., 2013. 1-allyl-3-methylimidazolium chloride pretreatment of seaweed industrial waste for bioethanol conversion. J. Renew. Sustain. Energy 5 063111.

Wei, N., Quarterman, J., Jin, Y.S., 2013. Marine macroalgae: an untapped resource for producing fuels and chemicals. Trend. Biotechnol. 31, 70-77.

Weldemhret, T.G., Nisola, G.M., Valdehuesa, K.N.G., Lee, W.K., Ramos, K.R.M., Chung, W.J., 2019. Ionic liquid pretreatment in tandem with recombinant agarase cocktail saccharification of gelidium amansii for d -Galactose and 3,6-Anhydro- 1 -Galactose 
Production. ACS Sustain. Chem. Eng. 7, 7563-7571.

Wu, X., Jampala, B., Robbins, A., Hays, D., Yan, S., Xu, F., Rooney, W., Peterson, G., Shi, Y.-C., Wang, D., 2010. Ethanol fermentation performance of grain sorghums (Sorghum bicolor) with modified endosperm matrices. J. Agric. Food Chem. 58, 9556-9562.

Xiao, X., Si, X., Yuan, Z., Xu, X., Li, G., 2012. Isolation of fucoxanthin from edible brown algae by microwave-assisted extraction coupled with high-speed countercurrent chromatography. J. Sep. Sci. 35, 2313-2317.

Yang, J., He, Q. (Sophia), Yang, L., 2019. A review on hydrothermal co-liquefaction of biomass. Appl. Energy 250, 926-945.
Yuan, Y., Macquarrie, D.J., 2015. Microwave assisted acid hydrolysis of brown seaweed ascophyllum nodosum for bioethanol production and characterization of alga residue. ACS Sustain. Chem. Eng. 3, 1359-1365.

Yun, E.J., Kim, H.T., Cho, K.M., Yu, S., Kim, S., Choi, I.G., Kim, K.H., 2016. Pretreatment and saccharification of red macroalgae to produce fermentable sugars. Bioresour. Technol. 199, 311-318.

Zdanowicz, M., Wilpiszewska, K., Spychaj, T., 2018. Deep eutectic solvents for polysaccharides processing. A review. Carbohydr. Polym. 200, 361-380.

Zhang, C., Show, P.L., Ho, S.H., 2019. Progress and perspective on algal plastics - a critical review. Bioresour. Technol. 289121700. 